\title{
The Potential Impact of Art Therapy Approaches in an Alternative Learning School Setting in Urban West Virginia
}

Brianna Saddler

Follow this and additional works at: https://researchrepository.wvu.edu/etd

\section{Recommended Citation}

Saddler, Brianna, "The Potential Impact of Art Therapy Approaches in an Alternative Learning School Setting in Urban West Virginia" (2017). Graduate Theses, Dissertations, and Problem Reports. 6553. https://researchrepository.wvu.edu/etd/6553

This Thesis is protected by copyright and/or related rights. It has been brought to you by the The Research Repository @ WVU with permission from the rights-holder(s). You are free to use this Thesis in any way that is permitted by the copyright and related rights legislation that applies to your use. For other uses you must obtain permission from the rights-holder(s) directly, unless additional rights are indicated by a Creative Commons license in the record and/ or on the work itself. This Thesis has been accepted for inclusion in WVU Graduate Theses, Dissertations, and Problem Reports collection by an authorized administrator of The Research Repository @ WVU. For more information, please contact researchrepository@mail.wvu.edu. 
The Potential Impact of Art Therapy Approaches in an Alternative Learning

\author{
School Setting in Urban West Virginia
}

\author{
Brianna Saddler \\ Thesis submitted to the College of Creative Arts at West Virginia University \\ in partial fulfillment of the requirements for the degree of \\ Masters of Art Education \\ West Virginia University College of Creative Arts \\ School of Art \& Design
}

Terese Giobbia, Ph.D., Chair
Alison Helm, MFA
Joseph Lupo, MFA
Department of Art Education

Morgantown, West Virginia

2017

Keywords: Art therapy approaches

Copyright 2017 Brianna Saddler 


\title{
ABSTRACT \\ The Potential Impact of Art Therapy Approaches in an Alternative Learning School Setting in Urban West Virginia
}

Brianna Saddler

\begin{abstract}
Now more than ever American adolescents are suffering from severe anxiety (Lewis, 2017). In the past, over-achieving students were those parents least worried about when it came to experiencing anxiety but now studies show these students are just as likely to experience anxiety as those learners considered to be underachievers. The purpose of this paper is to inform the reader how art therapy approaches embedded into daily lesson plans could be used in alternative learning school settings to help students deal with anxiety. Through my own experiences as a practicing art teacher in both general education art classrooms and alternative learning school settings, this paper explores how using specific art therapy approaches may help students deal with some of the social stressors they face every day in these classrooms. While more research is needed to identify lessons that will engage students in creating meaningful and purposeful art, which will help to reduce stress among this group, this paper is a starting point to help students deal with their stress caused by many outside factors from family and social life to feelings of failure and inadequacy.
\end{abstract}




\section{Table of Contents}

\section{Acknowledgments}

\section{Chapter 1 Introduction}

1.1 Study Topic

1.2 Personal Perspective

1.3 Significance of Study

1.4 Problem Statement

1.5 Summary

\section{Chapter 2 Literature Review}

2.1 Introduction

2.2 An Overview of Theories and Techniques in Art Therapy

Expressive Arts Therapy;

Person Centered Art Therapy

Gestalt Art Therapy

Creative Connections Art Therapy

2.3 Art Approaches Used in Secondary Schools in West Virginia

2.4 Art Approaches Used in Alternative Learning Settings in West Virginia

2.5 Self Efficacy

2.6 Summary

\section{Chapter 3 Methodology}

3.1 Introduction

3.2 Phenomenological Research Approach

3.3 Participants

3.4 Settings

3.5 Summary

\section{Chapter 4 Data Analysis}

4.1 Introduction

4.2 Lesson Plan

4.3 Clinical Setting

4.5 Summary

\section{Chapter 5 Findings}

5.1 Discussing of the Findings

5.2 Summary of the Findings

5.3 Implications of the Findings

5.4 Suggestions for Future Research 


\section{List of Figures}

Fig. 1 - The individual creative force

Fig. 2 - Example of Silver Drawing Test

Fig. 3 - Example of Draw a Story

Fig. 4 - Example of Person Picking an Apple

Fig. 5 - Example of student A's outside of box

Fig.6 - Example of student A's inside of box

Fig. 7- Example of student B's outside of box

Fig. 8 - Example of student B's inside of box

Fig. 9 - Example of student C's outside of box

Fig. 10 - Example of student C's inside of box

Fig. 11 - Example of student D's outside of box

Fig. 12- Example of student D's inside of box

Fig.13 - Example of therapist drawing with client

Fig. 14 - Personal Journal Entry 


\section{Acknowledgements}

I would first like to thank my thesis advisor Dr. Terese Giobbia of the School of Art and Design at West Virginia University. The door to Dr. Giobbia's office was always open whenever I ran into any issues or had a question about my research or writing. Dr. Giobbia pushed and held grand expectations, and I would not be where I am without her support. She was consistently working with me to get my thesis to be the best that it could be. I owe her everything for getting me through this process.

I would also like to acknowledge Joseph Lupo, and Alison Helm of the School of Art and Design at West Virginia University as my additional readers of this thesis, and I am gratefully indebted to their valuable time and comments on this thesis.

Finally, I want to express my appreciation to my parents for providing me with loving support and continuous encouragement throughout my years of study and through the process of researching and writing this thesis. It's incredibly humbling to be the first in my family with a master's degree. I know that my mother and father are incredibly proud of me. This accomplishment would not have been possible without them. Thank you. 


\section{Chapter One}

Introduction

Today's students have changed drastically over the past decade (Foorester, 2017). As students in today's contemporary society change, approaches in teaching must also change. Today's students face more issues that their predecessors did and in facing these issues, students have made learning less of a priority. The positive atmosphere that a classroom can bring to a student can change the student's life, particularly if the student is given so many ways to succeed. "Students who take art, learn the balance of structure and freedom to express" (Foorester, 2007, p. 6). Art may be able to help students find multiple ways to cope with these challenges.

When students create art, they take ownership of their work. In many cases, art is the only opportunity presented to these students to express themselves. Self- expression can impact the student's peers and surroundings, because showing artwork and taking ownership of it may improve the students' self-esteem (Foorester, 2007). "In an art class, the student learns how to understand what is an aesthetically pleasing work of art and develops a desire to comprehend the world which results in a more well-rounded individual" (Foorester, 2007, p. 7). Partaking in art sparks a curiosity that may not be found in other subjects a student takes. When a student is assigned a project, it is up to the student to plan and organize the message he or she wants to create (Foorester, 2007). They must think about what to create, what supplies will be needed, make it happen and then let their thoughts come out. When a student does not have the words to speak, many use their art to communicate their thoughts and ideas. Visual skills are learned in the art classroom, a place like no other classroom. One's response to art can be compared to the way they respond to any given situation. The way one looks at art can make them more sensitive to real life situations. Something that has been taught in the art classroom for many years is that 
one's view of art is based on their individual qualities. That is what makes everyone unique and interesting (Foorester, 2007).

\subsection{Study Topic}

American teenagers now more than ever are suffering from severe anxiety (Lewis, 2017). In the past over-achieving students were the last people parents and teachers worried about but now studies are pointing to how these students are just as likely to experience anxiety as those students considered to be underachievers. A recent article appearing in the New York Times magazine points the blame at a variety of factors, including taking an overload of advanced and/or honors placement courses, afterschool sports programs, extraneous travel to and from school sponsored field trips and functions, as well as a stressful home and/or social life (Lewis, 2017). With so many pressures put onto these students today, could art be seen as an outlet to express one's anxieties, fears and frustrations?

Jake, a student featured in the Lewis (2017) article, was a normal over-achieving high school junior. Stemming from a feeling of failure, Jake worried in private about not being able to keep up with his peers and whether he could succeed in life (Lewis, 2017). He considered his “drive to avoid this fate deep within him his strength" (Lewis, 2017, p. 1). Jake's parents were aware he could be a little high strung, a personal trait that emerged in middle school. As a result, he was sent to a therapist when he became too scared to sleep in his room alone in his junior year. In the same year, Jake stopped attending school and curled up in the fetal position screaming "I just can't take it! You don't understand!" (Lewis, 2017, p. 10). When Jake was just 17 he drove his car 150 miles per hour into a brick wall. 
The purpose of this paper was to explore how different art approaches could be used in an alternative learning school art classroom as a way for students to deal with internal and external factors that caused anxiety. Through observations; document analysis of lesson plans of my own teaching and resulting student art activities, this paper explored the different art and art therapy approaches employed in these art classrooms. This paper offers a personal perspective on how certain art approaches could be used to positively impact students who seek their education at alternative learning school settings and specifically discusses the art therapy approaches that appeared to positively impact students' social and artistic behaviors. The research questions which framed my discussion are:

1. What art approaches are used in secondary school settings?

2. What art approaches are used in alternative learning school settings?

3. What art therapy approaches are used in alternative learning settings?

\subsection{Personal Perspective}

Despite the studies that show how important art education is to the emotional wellbeing of adolescents, art may not be offered in all elementary, middle or high schools or the Alternative Learning School setting. And there exists a vast difference with the students who have art class every morning for forty-five minutes and those who may have it once a month, which also varies from semester to semester. The students who participate in art are more likely to have conversations with each other more often, especially as they collect their own art supplies. In a poll conducted on the attitudes of Americans toward arts education, results showed that $93 \%$ agreed "arts are vital to providing a well-rounded education for our children" (Ruppert, 2006, p. 4). Ruppert's study also demonstrated how the arts go hand in hand with education, working with in conjunction with the other core subjects to promote the wellbeing of the child as "schools 
integrating the arts into the curriculum as part of a comprehensive education reform strategy are documenting positive changed in the school environment and improved student performance" (Ruppert, 2006, p. 1).

I have seen firsthand how students are affected by the quantity of art instruction they receive within the school year. I have taught in a school system where I saw my students weekly and I have taught in a school system where I saw them once a month. The students I saw once a week learned a lot about art, enjoyed having bigger more elaborate projects that could carry over into the next week and were also exposed to more professional art work and art history. These students had more developed and cohesive lessons with information about a famous artist or art period included in their curriculum. The students who had art just once a month only were able to have lessons that focused on making art. Each art lesson had to be completed in one visit and it could not carry over into the next class, which was the next month. Schools that had art planned in the winter months and over holidays suffered the most when the schools were closed. Art classes were never rescheduled, rather they would be moved to the following month. As a result, students would sometimes not have art for two to three months.

As a practicing art teacher who has taught in both an alternative learning school setting as well as in regular school settings, I have seen firsthand how certain art therapy approaches can help students in the Alternative Learning School setting grow and flourish both socially and artistically. The amount of art instruction time a student receives in an alternative learning school setting widely varies depending on the school and area they are in. In the state of West Virginia, alternative learning schools are being used to mainstream the population of students who are often referred to as at risk students (Personal communication, guidance counselor at the alternative learning school). These students are at risk and need to find an alternative learning 
school setting to prevent a dropout situation. "An important factor in at-risk student success in the school was the development of caring relationships with other students, teachers, and administrators" (Bland, Church, Neill, \& Terry, p. 31).

The content being taught at these schools does not include some common core subjects such as art. However, studies demonstrate that when art is used as an approach to help students with emotional and social disorders, students can greatly benefit (Ruppert, 2006) The "environment in which the students feel safe and know that teachers respect and care for them is also a big factor when the students choose to come to the alternative learning school environment" (Bland, Church, Neill, \& Terry, p. 31) .

\subsection{Significance of Study}

The benefits that the arts can bring to students is endless. Studies show art provides a wide array of tangible and intangible academic and social benefits and have a positive impact on the wellbeing and social and emotional development of an adolescent (Byrant, 2017; Eisner, 1984; Ruppert, 2006). “The fine arts provide learners with non-academic benefits such as promoting self-esteem, motivation, aesthetic awareness, culture exposure, creativity, improved

emotional expression, as well as social harmony and appreciation of diversity, these are the very fibers of the fabric known as our American culture" (Bryant, 2017, p. 1)

The arts are connected to creativity (Roundtable, 2017). Students that are enrolled in many arts activities showed upfront evidence of an understanding of multiple vantage points of creativity cultivation and comprehension (Roundtable). When students learn in the arts, this positively reinforces the student's ability to think critically (Roundtable). "Employers believe that applied skills, such as critical thinking, problem solving, teamwork, and 
creativity/innovation, will surpass basic knowledge such as reading comprehension, mathematics, science, and history/geography on the combined list of skills that respondents say will increase in importance over the next five years" (p. 6). When investigating the effect of an arts education on later employment, the rate of employment was higher among young people leaving school later who took the arts subjects, compared to those who did not (Roundtable). When students took at least two art subject classes these students tended to have a higher rate of achieving employment than those who only enrolled in one arts class (Roundtable). The arts have shown benefits even to those students who leave school at the earliest opportunity. For students who leave school before they graduate, employment is generally higher for those who have at least had art courses in their curriculum (Roundtable). Young students that have student's music or a graphic communication are among the most employable of those students who decide to leave school early (Roundtable).

\subsection{Problem Statement}

Students are coming to school under pressures that sometimes teachers, faculty, and administrators do not always see. A recent journal article in the New York Times Magazine explains why teenagers are becoming increasingly more anxious. "We've always had kids who didn't want to come in the door or who were worried about things," says Laurie Farkas, who was until recently director of student services for the Northampton public schools in Massachusetts, "but there's just been a steady increase of severely anxious students" (Lewis, 2017, p. 2). One student [in the article] said that he would get anxiety if he failed a single quiz at school, then he would fail the class and then no longer get to go to his dream college, that he would call himself a complete failure. "So many times," Farkas says, "students automatically go to the negative and see the absolute worst in things" (p. 2). 
Anxiety is the most common mental-health disorder in the United States, affecting nearly one-third of both adolescents and adults, according to the National Institute of Mental Health. But unlike depression, which routinely occurs, anxiety is often seen as a less serious problem" (Lewis, 2017, p. 3).

Studies support that when students are exposed to art, they can channel their negative energy and thoughts into positive learning outcomes yet in many places art is missing from the curriculum especially in alternative learning settings. Additionally, there is currently a gap in the literature on how students within Alternative Learning Schools might benefit from the inclusion of art in their curriculum. Because so few of these schools have integrated arts into their curriculum, this study aims to bridge the gap on how art can benefit students who come from this special population and how it may help foster student growth and improve self-efficacy.

Yet, the amount of art instruction a student receives in the K-12 classroom varies from state to state. In the United States, only 43 states require schools or districts within their state to provide arts instruction, yet not all schools mandate that art be taught as part of the curriculum (Ruppert, 2006, p. 1). In West Virginia, this varies from county to county, and school to school. Art may be offered to elementary, middle and high schools, or it can be offered to just solely the upper grades. Looking at an art course list for County A in West Virginia, art is offered from kindergarten through $8^{\text {th }}$ grade, and then Art I, II, III, IV, AP Art, Computer Assisted Art, Textiles, and Visual Art Independent Study re offered at the secondary school level (West Virginia Department of Education, 2017). Compared to a District in Pennsylvania where art is offered to kindergarten through $9^{\text {th }}$ Grade and then Art Exploration, Drawing and Painting, 2D/3D Design, Human Figure, Portfolio Prep, Ceramics I, II, and III, Art History I and II are 
offered to grades 10-12. In comparison, West Virginia is not offering a variety of, or challenging, art classes.

In West Virginia, 273,170 students were enrolled in public education (West Virginia Department of Education, 2017). School systems in West Virginia are divided among 55 counties and operate within those borders. The counties are then further broken down into eight RESAs (Regional Education Service Agency) within the state, which have between $4-12$ counties in each RESA. Each county has elementary, middle and high schools, some counties have alternative learning setting schools. There are currently only 10 schools in public education that are listed as other in the state that do not fit the category of elementary, middle, high, or career and technical schools.

As stated above West Virginia only has 10 other schools listed in the public education system. Those 10 schools do not even have guarantee of art therapy being offered there. If art therapy was offered in schools working alongside of guidance counselors, many students would benefit. The students would be better socially, they would have more self-confidence, and some would be able to communicate their feelings more effectively. I observed when art was offered in an Alternative Learning School, the students participating in art started opening up and talking about their personal lives and how art has helped them. By tying art therapy and Albert Bandura's self-efficacy together, the statement from before could be true. Bandura states that “Self-efficacy is the belief in one's ability to influence events that effect one's life and control over the way these events are experienced" (Buchanan, 2017, p. 1). Seeing firsthand that when students are working on art and are distracted, they seem to speak more to their peers at the table and seem to be in a better mood as well. Regardless of the type of day the student had, he or she shared the events that were involved, and it could easily be seen that stress levels decreased. 


\subsection{Definition of Terms}

Art Approach- how one goes about to make their own art

Art Therapy- as defined by the American Art Therapy Association (AATA) is an integrative mental health and human services profession that enriches the lives of individuals, families, and communities through active art-making, creative process, applied psychological theory, and human experience within a psychotherapeutic relationship (Sarah, 2017)

Creative Connection Art Therapy - "The creative connection developed by Natalie Rogers discusses how an art form stimulates and fosters creativity through another art form, linking all the arts to our essential nature" (Rogers, 2016, p. 232)

Expressive arts therapy - "Expressive arts therapy can include any of the following; movement, drawing, painting, sculpting, music, writing, sound, and improvisation" (Rogers, 2016, p. 232)

Person centered art therapy - Natalie Rogers describes person centered arts therapy as having the therapist be all the following; empathetic, open, honest, congruent, and caring (Rogers, 2016)

Gestalt art therapy - Created and developed by Fritz Perls, Laura Perls, and Paul Goodman in the 1940's, gestalt arts therapy is an experimental and humanistic form of therapy. Gestalt therapy is that people are linked to and influenced by their surroundings, and that everyone is striving toward growth and balance. (Gestalt Therapy, 2017).

Art therapy approaches - the collection of multiple ways to administer art therapy 
Alternative Learning Setting- The alternative school is an educational setting designed to accommodate educational, behavioral, and/or medical needs of children and adolescents that cannot be adequately addressed in a traditional school environment (Sisk, 2017)

Self-Efficacy- "is the belief in one's ability to influence events that effect one's life and control over the way these events are experienced" (Buchanan, 2017, p. 1)

\subsection{Summary}

As society changes and students needs evolve and change, approaches in teaching need to change (Foorester, 2017). American teenagers are suffering from anxiety now more than ever (Lewis, 2017). The arts can bring endless benefits to students. Students that are enrolled in many arts activities showed upfront evidence of an understanding of multiple vantage points (Roundtable, 2017). By participating in art courses students are becoming more employable and are benefiting themselves. Providing definitions, one can understand the different art terms that are being referred to. 


\section{Chapter Two}

Literature Review

\subsection{Introduction}

Alternative learning school settings began to appear in the United States during the 1970s. The alternative school is an educational setting designed to accommodate educational, behavioral, and/or medical needs of children and adolescents that cannot be adequately addressed in a traditional school environment (Sisk, 2017). Recognized as an alternative way to meet the needs of children and adolescents who cannot learn effectively in a traditional school environment (i.e., conventional public or parochial schools) due to learning disabilities, certain medical conditions, psychological and behavioral issues, or advanced skill. As alternative learning school settings incorporate self-confidence building into their curriculum, these settings help students grow on an individual basis, and enhance social skills as well as provide for more flexibility in organization and administration (Sisk, 2017). This chapter provides an overview of art therapy approaches and art approaches, assessments and art activities currently used in secondary and alternative learning school settings in urban West Virginia.

\subsection{An Overview of Theories and Techniques in Art Therapy}

Exposing students to art in educational settings and specifically in alternative learning settings invites critical thinking and empowers them with a greater understanding for seeing and appreciating the world around them (Freedman, 2003). As students learn about the specific components of art they develop the ability to communicate on greater cultural, personal and social levels. Approaches in art offer ways for students to learn how time and place influenced artists, resolve conflict, and give greater meaning to their own experiences. Art approaches 
include choosing materials, brainstorming ideas, and encouraging students to engage in meaningful discussions. Art therapy, which employs these same visual art approaches, such as drawing, painting, sculpture, and other art forms, helps people cope with trauma caused by many societal, psychological and/or physical issues. These same approaches, can be used to improve cognitive and sensorimotor functions, foster self-esteem and self-awareness, cultivate emotional resilience, promote insight, enhance social skills, reduce and resolve conflicts and distress, and advance societal and ecological change (AATA, 2017).

This section discusses the major art approaches used in art therapy - Expressive Arts Therapy; Person Centered Art Therapy; Gestalt Art Therapy, Creative Connections Art Therapy.

\section{Expressive Arts Therapy}

Expressive arts therapy can include any of the following; movement, drawing, painting, sculpting, music, writing, sound, and improvisation. These techniques are used in a supportive and safe environment with the client to experience and express feelings. The wonderful thing about expressive arts therapy is that all of the different techniques blend together so well that the client can use more than one to convey their feeling. Rogers states that "all art that comes from an emotional depth provides a process of self-discovery and insight” (Rogers, 2016, p. 230).

We show what is happening on the inside by creating forms on the outside, such as art. When feelings are expressed on the outside in visual forms, we are essentially using art as a new language to communicate. When the arts are used expressively that means that the client is reaching into their inner self to discover feelings and to explore and express themselves through visual art, movement, sound, writing, or drama, with no concern about the magnificence of the art, the grammar and style of writing, or the balance of sounds made. However, a thought- 
provoking or intense product may be produced, we can leave the craftsmanship to those who want to be professional artists. When art is used for therapy no judgment occurs, the result is expressing feelings not about the look or sound of the final piece.

The arts are used to let go, to express, and to release. Art therapists are aware that involving the mind, the body, and the emotions brings forward interesting and unaltered thoughts. Rogers says that emotional states are not usually logical, and the use of imagery and nonverbal modes allows the client an alternate path for self- exploration and communication (Rogers, 2016, p. 231).

\section{Person Centered Arts Therapy}

Natalie Rogers, a pioneer of Person Centered Arts Therapy, describes the person centered art therapist as one who is empathetic, open, honest, congruent, and caring. Rogers (2016) states that the therapist must listen in depth and facilitate the growth of the client or group. Person centered art therapy is the belief that every person has the worth, dignity, capacity for selfdirection, and potential for growth and development. The therapist should have an empathic understanding of the artwork as they discuss the artwork the client has made. Rogers describes this "empathic understanding" as one which accurately "senses the feelings and personal meanings that the client is experiencing and communicates this acceptant understanding to the client" (Rogers, 2016, p. 231). When functioning best, the therapist is so much inside the private world of the other that he/she can clarify not only the meanings of which the client is aware but even those just below the level of awareness. "Listening, of this very special, active kind, is one of the most potent forces for change that I know." (Rogers, 2016, p. 232). When a client communicates, the therapist is understanding toward the client, as it is very rare to feel accepted and understood when you are feeling fear, rage, grief, or jealousy. 
A question that is often brought to Rogers' attention is how she knows what to suggest in terms of art or movement or even sound with the client. There really is no direct answer, as art is never right or wrong. Rogers uses clues from the clients and she trusts their path that they choose. Rogers states that she follows the client's path, but she gives choices. When a client is showing strong emotions she asks "would you like to explore that emotion in a color or movement? If the client says no, then I need to talk more and that is also okay. If the client says, yes, I would like to explore that feeling more through art, she would then give them the choice of making art, move or make sound" (Rogers, 2016, p. 232). The client has the lead in their arts therapy, the choices are provided so the client understands the multiple options they have to convey that feeling. The client is then asked what the experience was like as they created the piece. The piece of art is then looked at by both the Art Therapist and the client together and the client is encouraged to describe it and give any meaning behind the piece. At this point the client is essentially allowing the therapist to enter their realm of thinking. If the client chooses movement instead of creating art, Rogers says she constantly asks "does this feel right to you? Do you wish to explore more? Am I understanding you correctly? Do I get your real meaning here?" She goes on to state that:

"It is always important to treat your clients with the same kind of respect you would want from a therapist. As a therapist, you must be careful in not to pre-judge a piece of art work. As the therapist, you do not want to say what the client is feeling, you want the client to tell you. If you misunderstand the client, the client may not trust you. If the therapist automatically assumes what the client is feeling, and the therapist is wrong then, the client may think I never want to show my artwork to them again. As a therapist, you want to make sure your client feels safe and un-judged. Stated from before, the art that is produced is not to be admired as much as used to release the energy that is inside of the client. Art is personal and very open to the client's feelings" (p. 235).

As a friend or therapist, it's often implied we must give advice or have the answers (Rogers, 2016). This honestly is not the case. Just by listening to the depth of the emotions 
behind the individual and respecting the individual's ability to find their own answer, we are giving the client the opportunity to empower themselves because they are discovering their own potential and discovering answers on their own (Rogers, 2016). When you are not giving the client the answer or advice it is forcing them to express how they feel either by talking about it or by being expressive, sometimes just by saying or doing things and discovering your own feelings is the best therapy (Rogers, 2016). You may get the chance to uncover something you may not have known you were keeping buried emotionally. Empathic listening helps to encourage the peeling of many layers back, which lets the client know you can be trusted and that they feel safe (Rogers, 2016). By doing this you as the therapist are making your client feel whole (Rogers, 2016).

\section{Gestalt Arts Therapy}

Created and developed by Fritz Perls, Laura Perls, and Paul Goodman in the 1940's, Gestalt Arts Therapy is an experimental and humanistic form of therapy. Gestalt therapy is used when people are linked to and/or influenced by their surroundings, and that everyone is striving for growth and balance (Gestalt Therapy, 2017). Gestalt therapy is closely linked to person centered therapy in that the gestalt therapist also uses empathy, understanding and absolute acceptance to let clients know they can trust the therapist. Context affects the experience and a client cannot be fully understood without the therapist knowing and accepting their personal context (Gestalt Therapy). Within this specific therapy, no one can be solely objective including therapists whose experiences and perspectives are also influenced by their own contexts. Forcing a client to change results may cause further distress. Creative and experimental techniques, such as using charcoal to create a piece of art around the body while sitting can be used by therapists 
and clients within this process. The processes help the client become more self-aware, have more freedom and self- direction (Gestalt Therapy, 2017).

The main idea behind this type of therapy is that it accepts what it is and focuses on helping the client learn to become more self-aware and to accept and trust their own feelings. Through therapy the client learns to discover feelings that may have been suppressed or hidden from other feelings and to accept and trust their emotions. Emotions and needs that were previously suppressed or misunderstood are likely to come to the exterior as well. Through this process the client gains a new sense of self-awareness (Gestalt Therapy, 2017).

The past is linked to the client's present experience. The main point in this therapy is to not dwell on the past, or anxiously anticipate the future. Rather, it is the therapist's job to have the client focus on the now, and how a client's environment or surrounding influences their lives (Gestalt Therapy, 2017). Times of the past may be visited in therapy sessions however, the therapist and client will focus on exploring why that memory came to the surface, or how the present time is impacted by the things that happened in the past.

Gestalt therapy sessions are not under a strict guideline for how the session goes. Therapists are encouraged to use creativity in their approaches. There is an emphasis on direct contact between the therapist and the client, direct experience and experimentation, and the focus on the what, how, here and now. Therapist try and stay away from interpreting events, concentrating on the now. Subtle comments such as commenting on a client's posture can bring the client back into the now. This can help the client understand physical cues and help them become more self-aware of their physical and mental emotions. Having the client understand the internal self is the key to understanding actions, reactions, and behaviors (Gestalt Therapy). 


\section{Creative Connection Arts Therapy}

The creative connection developed by Natalie Rogers discusses how an art form stimulates and fosters creativity through another art form, linking all the arts to our essential nature (Rogers, 2016). By using person centered therapy, Rogers made some personal discoveries. She found that when "I danced a sad or angry feeling in the presence of an empathic, nonjudgmental witness, my feelings and perceptions shifted dramatically. When I drew the images after moving, the art became more spontaneous, expressive, and revealing" (Rogers, 2016, p. 232). By following art with free creative spirit, Rogers found she dove further into her guarded feelings and thoughts. She then realized that the empathic witness to art, movements and journal writing was very similar to person centered therapy (Rogers).

Rogers developed a graph to show the individual creative force, which is shown in Figure 1 (Figure 1). She described this process as being similar to unfolding a lotus blossom on a summer day. 'In the warm, accepting environment, the petals open to reveal the flower's inner essence. Our feelings are trapped, but because they are in a warm, safe and inviting environment the petals bloom" (Rogers, 2016, p. 234). 


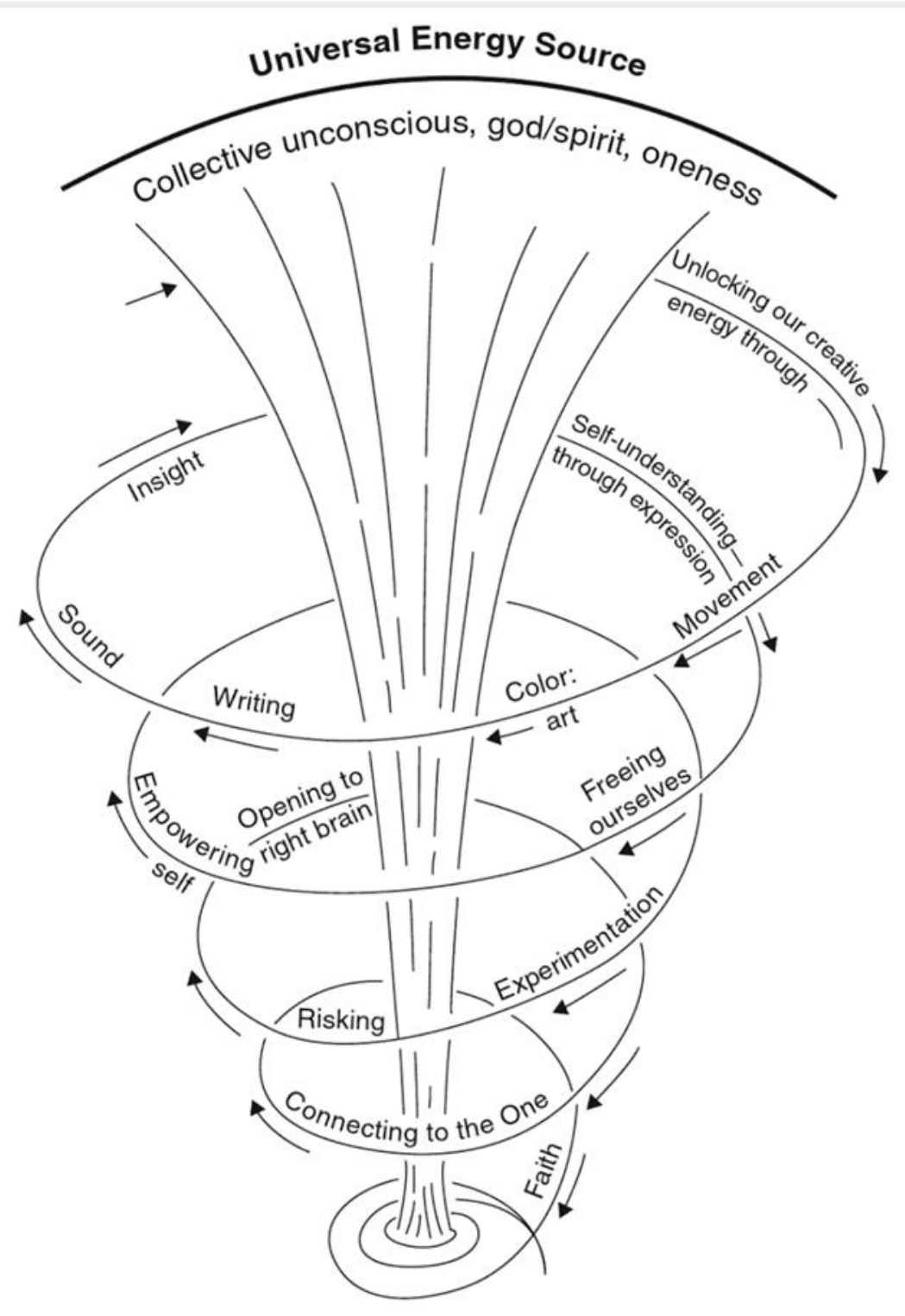

The Individual Creative Force

The Creative Connection Process: By moving from art form to art form, we release layers of inhibitions, bringing us to our center-our individual creative force. This center opens us to the universal energy source, bringing us vitalitv and a sense of oneness.

Figure 1 - The Individual Creative Force (Rogers, 2016, p. 236) 
Art therapists use art based assessments in a variety of ways. They can use them to "assess where clients are in therapy, to evaluate a client's personality and to show growth" (Malchiodi, 2014, p. 435). Within art therapy, four major assessments can be used and are defined as follows.

The Diagnostic Drawing Series (DDS) is a series of three drawings completed in one therapy session, with the following instructions:

1. Make a picture using these materials (unstructured task)

2. Draw a picture of a tree (structured task)

3. Make a picture of how you are, using lines, shapes, and colors - partially structured task (p. 435).

The DDS was created to determine if patterns of formal drawing elements would correlate with specific psychiatric diagnoses (Malchiodi, 2014). Just because this type of assessment is given to a client does not mean that a diagnosis will emerge. The DDS uses 20 categories grouped into formal elements of visual expression (Malchiodi). Such things looked at in the series are line and shape, line pressure, placement of elements, use of space, integrations or lack or integration, and other characteristics (Malchiodi). "Certain configurations identified by DDS have been correlated with symptoms found in individuals with depression and schizophrenia, Alzheimer's disease, and other diagnoses" (p. 436). The assessment for DDS is given with a package of 12 soft chalk colored pastels, and white 18 " x 24" drawing paper, preferably good quality with a slight textured surface (Malchiodi, 2014). Even if the client does not complete a drawing, the therapist still places that drawing in the client's series. When the assessment is complete the therapist will discuss the drawings with the client any discussion or 
thought are noted. The DDS assessment can be given to clients at age 13 and older and in 50 minutes or less (Malchiodi, 2014).

The Silver Drawing Test (SDT), first published in 1983, assesses cognitive skills and emotional strengths and provides access to perceptions of self and others. The SDT bypasses an individual's language deficiencies to determine intelligence of an individual (Malchiodi, 2014). The SDT can be given to clients individually or in a group setting, with adults and children over the age of 5 (Malchiodi). There are three parts to the SDT, which are predictive drawing, drawing from observation, and drawing from imagination (Malchiodi). The first two parts of the assessment are structured and ask the client to add to preprinted drawings. The predictive drawing looks at the client's ability to sequence and the ability to conserve, and to recognize consistency on spite of changes in appearance (Malchiodi). The observation drawing measures the client's ability to represent spatial relationships in height, width, and depth (Malchiodi). In drawings from imagination, clients are asked to choose at least two stimulus drawings (animals, people, objects, environments) (Figure 2) and to show these images interacting within the drawing (Malchiodi). This process then encourages the client to combine and represent an image with a possible story. The client would then be asked to add a title and story (Malchiodi). 


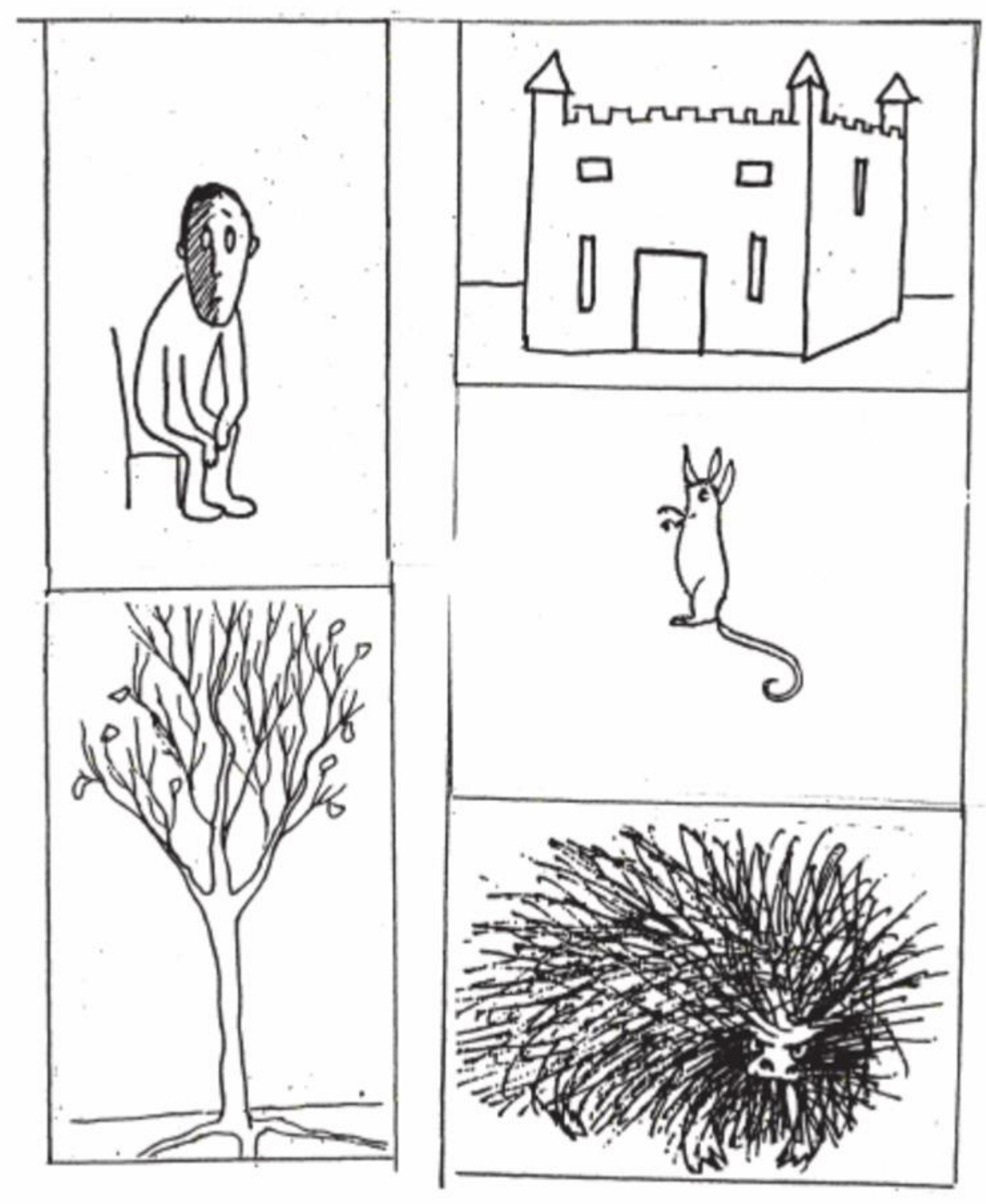

Figure 2 - Example of Silver Drawing Test 
“The Draw a Story (DAS) uses sets of "stimulus drawings" to prompt responses that solve problems and represent concepts" (Malchiodi, 2014, p. 437). These drawing include line drawings of people, animals, places, and things. Some drawings may be explicit, where others are vague to encourage associations (Malchiodi, 2014). Figure 3 depicts an example of draw a story. Responses to drawing tasks are assessed on a 5-point scale, while 5 is the highest score, and assessed are emotional content, self-images, and humor (Malchiodi, 2014). The DAS has been known to be used in evaluating children and adolescents at risk for depression and violent behavior (Malchiodi, 2014).

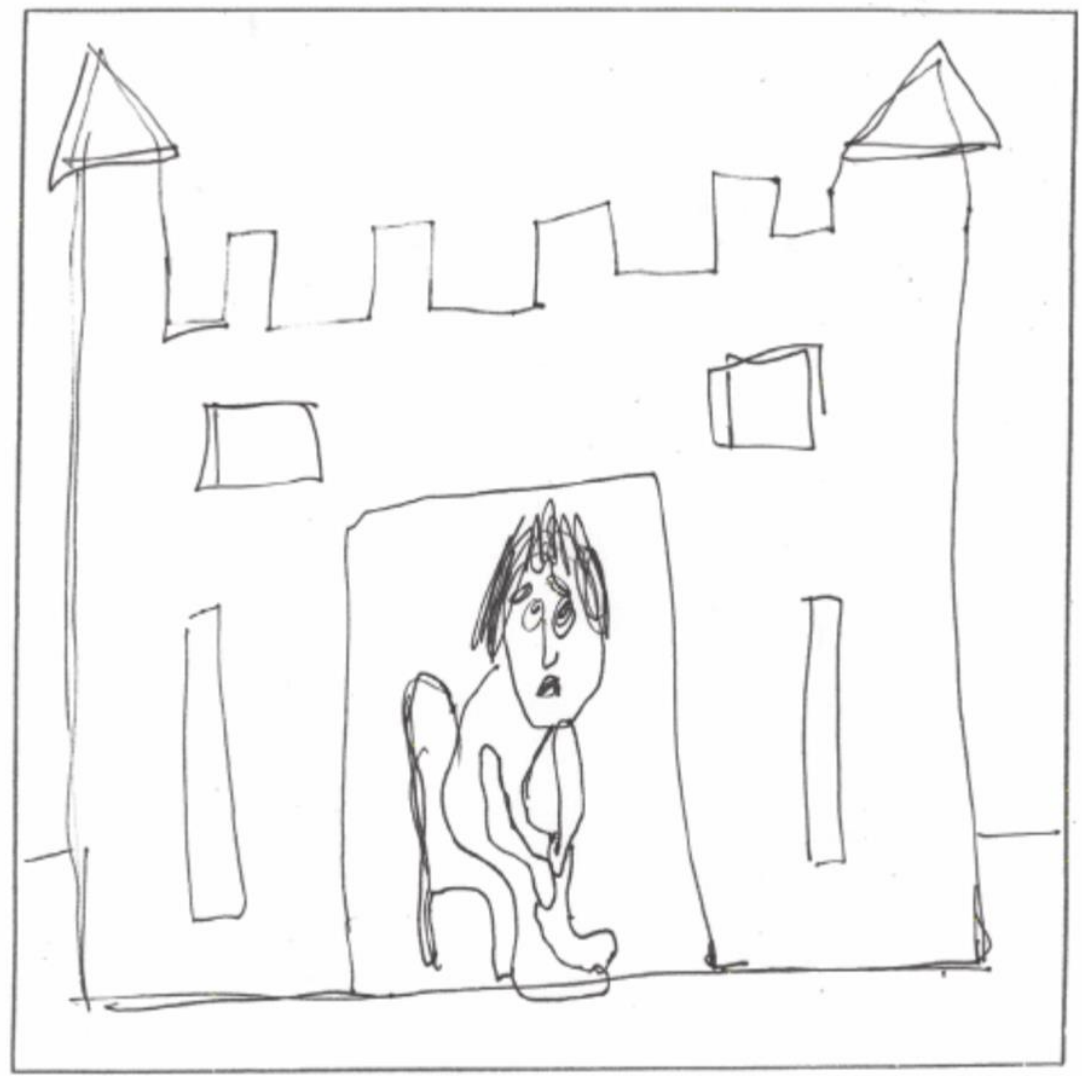

Figure 3 - Example of Draw a Story (Malchiodi, 2014, p. 439) 
The Formal Elements Art Therapy Scale (FEATS) is a set of 14 scales based on global, formal attributes and a set of content scales that code for specific colors, the gender of the drawn person, and additional items beyond a person, an apple, and a tree" (Malchiodi, 2014, p. 439). This process was originally developed to measure diagnostic information using the "draw a person picking an apple from a tree" (Malchiodi, 2014, p. 439). Draw a person picking an apple from a tree is constantly repeated to the client and if the client asks questions about gender or background the therapist just keeps repeating draw a person picking an apple from a tree. This process can be used with children or adults. Materials that should be included with this assessment are Mr. Sketch watercolors markers and white drawing paper 12" x 18" (Malchiodi, 2014, p. 439). The client is handed the paper so the client can determine the orientation of the paper and they are just asked to draw a person picking an apple from a tree (Malchiodi, 2014). (Figure 4) There is no time limit on this assessment.

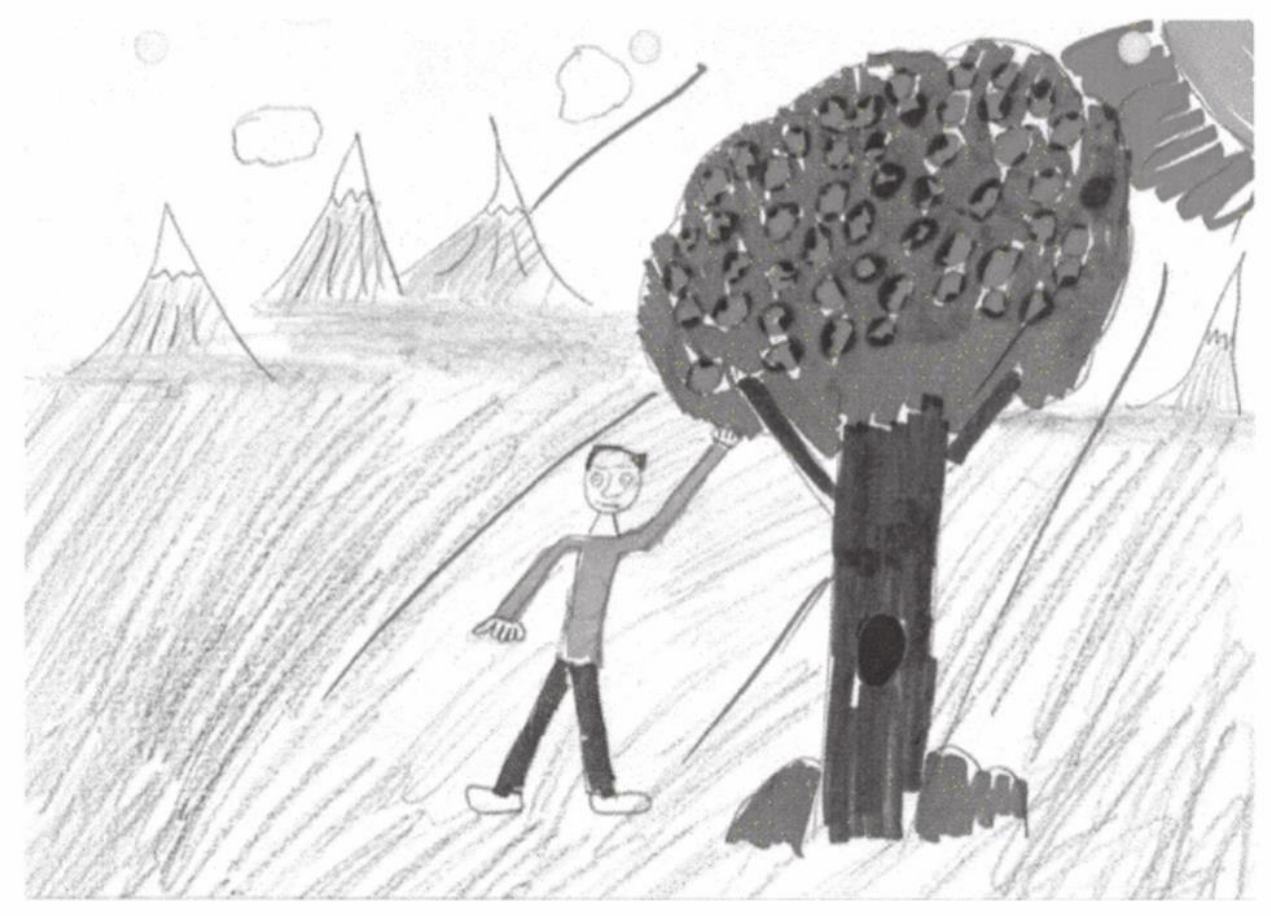

Figure 4- Example of Person Picking an Apple Tree (Malchiodi, 2014, p. 439 


\subsection{Art Approaches Used in Secondary Schools in West Virginia}

West Virginia follows State Standards known as CSO’s (Content Standards \& Objectives) When planning art activities, student interest is taken into account. What will the students enjoy working on, will they get easily frustrated with this assignment, will they be able to add their own creativity to the assignment? Art class can be a safe place where the students get to unwind and use their brain to think outside of the box. As the Art Teacher you need to have a healthy mix of the state standards, the students interest, and art budget for supplies in mind.

Today's teenagers are often put under so much pressure from school and home life that they suffer from anxiety.

"Over the last decade, anxiety has overtaken depression as the most common reason college students seek counseling services. Surveys that look at symptoms related to anxiety are also telling. In 1985, the Higher Education Research Institute at U.C.L.A. began asking incoming college freshmen if they "felt overwhelmed by all I had to do" during the previous year. In 1985, 18 percent said they did. By 2010, that number had increased to 29 percent. Last year, it surged to 41 percent" (Lewis, 2017, p. 1).

Anxiety is viewed as a less fundamental problem and is often overlooked, even though anxiety is the most common mental health disorder in the United States, affecting one -third of both adolescents and adults (Lewis, 2017). Anxiety can be easy to overlook and dismiss because according to Philip Kendall everyone has it to some degree (Lewis, 2017). "And yet addressing anxiety is low on the priority list in many economically disadvantaged communities. Kids who "act out" are often labeled defiant or aggressive, while those who keep to themselves — anxiety specialists call them "silent sufferers" - are overlooked or mistaken for being shy" (Lewis, 
2017, p. 4). For many students they often feel that they "never get to the point where they can say, 'I've done enough, and now I can stop,' " Luthar says. “There's always one more activity, one more A.P. class, one more thing to do in order to get into a top college. Kids have a sense that they're not measuring up. The pressure is relentless and getting worse" (Lewis, 2017, p. 5).

There are other things that may give stress or anxiety to students such as their home life and what it's like to live there. Some students may have to have a job to support their families at home by helping to pay the bills. High school can often feel like a full-time job to a teenager but to add additional home life pressures on top of that can really add stress to the student. The way that the student's peers perceive them can also add additional stress. If the student is liked or disliked and bullied, can affect the way the student gets through their day at school. Students are faced with all kinds of obstacles in their life and to take a time out and have the time to create art could greatly affect the way students handle their stress.

By definition, art therapy is a

"mental health profession in which clients, facilitated by the art therapist, use art media, the creative process, and the resulting artwork to explore their feelings, reconcile emotional conflicts, foster self-awareness, manage behavior and addictions, develop social skills, improve reality orientation, reduce anxiety, and increase self-esteem. A goal in art therapy is to improve or restore a client's functioning and his or her sense of personal well-being" (AATA, 2017, p.1).

Art therapy can have the potential to help any child experiencing learning, behavior, and emotional problems. It is stressed that art can potentially open up a nonverbal form of communication for those students who have a hard time communicating their thoughts and 
feelings through words. The art therapy used for this can help the students better know their emotions, know themselves, and cope with obstacles they face in life and at school. Studies have shown that children who are asked to draw while they talk reveal more information that those children who are just asked to talk. These findings show that while using art for talking it reduces children's anxiety, anger, and fear, and it allows for a stronger connection with the interviewer.

The literature presented discusses a basic understanding of art therapy in schools. The literature also suggests the need for art therapy and budgets that need to be set aside for art therapy in the schools. As stated in the article the use of art therapy in a school setting is not being widely utilized, and schools are finding it difficult to fund the budget to hire a properly trained individual to perform this type of psychotherapy (Says, 2017). However, reports of this kind of therapy is more valuable to reaching some students who might resist the more traditional routes of talk therapy. If more research was presented about how the effects of art therapy is changing the way young adolescents are communicating, then art therapy could be a normal element that makes up a school. For students who do not use words to communicate, but could draw a picture instead could make their school day go smoother. They could communicate better and have a stress-free day. Art therapy can help those students who do not want to talk days better as well, they could express themselves using various art mediums and could release feelings. If more evidence was presented to schools showing how valuable art therapy is, schools could not only teach students but make them feel safe and understood.

\subsection{Art Approaches Used in Alternative Learning Settings in West Virginia}

Person centered art therapy as well as Gestalt therapy were mainly used in the alternative learning school classroom. The classes that students are placed into are small in class size. The teacher to student ratio is small, which helps the teacher have a more individual instructions basis 
with the students. Lessons are based on the individual student's ability, which can be planned for because of the small class size. Teachers would base their lesson plans from their particular class. They would still follow state standards; however, they may only cover one standard every so many classes and not a standard a day. The classroom is going to be set up, so it is a nonthreatening, safe environment for all within the classroom. All desks are going to face the front of the classroom so that when the teacher is talking effective instruction can happen.

\subsection{Self- Efficacy}

Self-efficacy, one's own belief to influence events that effect one's life and control over the way these events are experienced (Buchanan, 2017). Bandura believes that there are four ways to build up one's self- efficacy: mastery experiences, social modeling, social persuasion, and states of physiology (Buchanan, 2017). Mastery experiences is experiencing the results first hand. The focus is to approach life with loyal efforts and setting realistic but challenging goals. Vital to mastery is feeling the great satisfaction of achieving these goals. Living through failure is also important, so that we can build resistance to it. This is accomplished by treating one's failures as learning opportunities and a chance to complete a task by taking a different approach (Buchanan, 2017).

Social modeling is choosing role-models that can demonstrate great self-efficacy. Having someone who shows that is their life that one can observe can provide great motivation. Living in today's society one does not have to view a role-model from close social circles but may take to the internet and social media and find one there (Buchanan, 2017).

Social persuasion is all about finding the right mentor. Social modeling focuses on observing while social persuasion is about others directly affecting one's self- efficacy. That is 
why it is crucial to have a mentor who practices good self-efficacy and one can use that influence to positively change and affect one's life. It helps to find a mentor who practices what they preach (Buchanan, 2017). States of physiology is our emotions, moods and current physical state. These can influence our self-efficacy. It is easy to judge one self-based on the current mood or mind set when failure happens. Positive and negative emotions serve as magnets and influence one's sense of self-efficacy, especially when one is depressed, and control can feel far from reach. By understanding that it is normal and okay to experience such mental states, one can move past these emotions and learn to handle negative times (Buchanan, 2017).

\subsection{Summary}

Exposing students to art invites critical thinking and empowers them with a greater understanding for seeing and appreciating the world around them (Freedman, 2003). The 4 major art therapy approaches - Expressive arts therapy, Gestalt art therapy, persona centered art therapy and creative connections art therapy can all be used to help individuals deal with emotional trauma and/or social stressors in a supportive and safe environment. These art therapy approaches can stimulate and fosters creativity and link us to our essential nature (Rogers, 2016). Art therapists use art based assessments in a variety of ways. They can use all of them to asses where they are in therapy, to evaluate their personality, and to show growth (Malchiodi, 2014). 


\section{Chapter 3}

Methodology

\subsection{Methodology}

Using phenomenology, this paper followed the researcher's own firsthand experiences of using art therapy to help deal with personal trauma. This personal trauma can be one of many things such as anxiety, death, stress or anything that may disrupt the persons everyday life. Through this proposal, the researcher was able to determine how using specific art therapy approaches in the art classroom may help students deal with some of the social stressors they face every day. While more research is needed to identity lessons that will engage students in creating meaningful and purposeful art, this proposal is a starting point to help students deal with their stress caused by their everyday life situations, their home life and their future.

\subsection{Qualitative Phenomenological Research Approach}

This topic is evaluated using a qualitative research method. Qualitative data includes rich narratives, descriptions, and visual aids, and lacks numerical information contained in quantitative data. This information for this analysis comes from artwork. There is no right or wrong answer when it comes to the evaluation of artwork. "Qualitative research is interpretative research, with the inquirer typically involved in a sustained and intensive experience with participants." (Creswell, 2003, p. 184).

For this topic, the Phenomenological research approach appeared to be the most appropriate qualitative method. Edmund Husserl, considered to be the founding father of phenomenology developed this approach as a way to provide an alternative to collecting quantitative data, as well as providing a means to analyze phenomenological events in a quest for 
knowledge (Aspers, 2009). Phenomenological research "describes a "lived experience" of a phenomenon" (Waters, 2017, p. 1). A case study would not have been appropriate because the researcher was not looking at a single instance or client. Observations were also not appropriate, because the case study method would give information about technique rather than final product to analyze. Quantitative methods were not appropriate as art products are not quantitative or numerical and therefore the phenomenological research approach was considered to be most appropriate for this paper.

The students in this paper all faced the same issue: anxiety. In analyzing anxiety, and dealing with anxiety through art, Phenomenology is the most appropriate research method (Denzin, 1985). The students observed were stressed on some level about something going on in their life. Students were allowed to pick their topic of feeling. The researcher only provided the main idea; the students made their own work based off of their feelings and opinions.

"Any way the participant can describe their lived phenomenal experience can be used to gather data in a phenomenological study. You can use an interview to gather the participants' descriptions of their experience, or the participants' written or oral selfreport, an observation of their behavior, or even their aesthetic expressions (any artistic expression can be data, including art, music, narratives, drama, poetry, dance, or film)" (Waters, 2017, p. 1).

Students were given an art project to work on to help them describe their feelings or emotions. This method was used with as most non-direction as possible (Waters, 2017). By not giving direction, the results were non-biased and Art as a non-direction subject should be interpreted by the artist themselves. 


\subsection{Participants}

The participants for this topic were chosen as a convenience sample. This was done as these participants were convenient for the researcher to access. A convenience sample is defined as "a sample that is easily accessible or a group of individuals who (conveniently) are available for study" (Fraenkel \& Wallen, 2006, p. 100). The participants were also part of a non- random, purposeful sample. "Purposeful sampling is based on the assumption that the investigator wants to discover, understand, and gain insight and therefore must select a sample from which the most can be learned" (Merriam, 1998, p. 61). The participants were those students who attended the regular secondary classroom setting and the alternative learning setting and are both pulled from the same geographic area. The students who attend the alternative learning setting have a home school, meaning they report to and then are transported to the alternative learning setting from there. Students can elect to go to the alternative learning setting if they feel the need to get away from their home school, need a smaller class size. If students have behavior issues at their home school, then they do not have a choice and they must attend the alternative learning school.

From this particular rural area in West Virginia, many are faced with drug problems, farm life, small school settings, and multiple sibling families. Often times these students are faced with knowing someone who sells or does drugs. Some students also live on family farms and have to work to help the family. The average graduating class from a regular high school in this area is around 125 students compared to a more populated area in West Virginia with around 440 students graduating (West Virginia Department of Education, 2017). 


\subsection{Settings}

\section{$\underline{\text { Setting A - Regular Art Classroom }}$}

The regular classroom for art class in the secondary school is considered very large (a minimum of 25 students). This classroom space is only used for art class. No other classes take place in or during any of the art classes. It has tables that seat four students to a table, which are placed in a U shape so that students can sit on either side. The teacher's desk has its own place by the chalkboard. A double sided multiple faucet sink is also placed in the back of the classroom, for easy cleanup, with its own paper towel dispenser. Cleaning supplies are stored under the sink and students are required to clean their own workspace before leaving class to ensure the tables are clean for the next class. The classroom also has a Viso TV screen to show students anything electronic to be viewed. There are multiple cabinets that are filled with various art supplies such as Prisma Colored Pencils to acrylic paint to an entire cabinet that is just dedicated to ceramics.

This art room is equipped with a fully functioning kiln, so that ceramics can be made. Other cabinets include a painting cabinet, craft cabinet, AP studio art cabinet, matte and frame cabinet, and paper cabinet. A separate display case with lights is also attached to the classroom so that student artwork can be displayed for everyone to see without anyone touching it. It gives a very clean and museum like feel to the student's artwork. Classes that are offered to these students are: Drawing, Ceramics, AP Studio Art, and Art I, II, and III. Class size ranges between 25-35 students.

\section{Setting B - Alternative Learning Setting}

The classroom has tables in the classroom that can seat four to a table. The tables are arranged in three rows. Health class is also in this classroom at the same time as art class, so the 
room is often split without any real dividers. Students from both classes can clearly hear instruction from either subject. One projector was in the classroom for both subjects to share, the teachers would have to coordinate who was using the projector on what day to ensure that each class could use it. There is one cabinet of art supplies provided for the students which included the basic art supplies. Students often would have to share their supplies. There is no kiln or sink in the classroom. Students would need to go to the restroom to clean out their brushes if they were painting or doing anything messy that day. Class size ranged from 3-8 and only Art I was offered to these students.

\subsection{Summary}

In summary this approach is the best way to approach this topic because, Phenomenological research is to "describe a "lived experience" of a phenomenon" (Waters, 2017, p. 1). Using phenomenology, this paper followed the researcher's own firsthand experiences of using art therapy to help deal with personal trauma. Students attending a regular

high school or the alternative high school all face similar stressors in their lives. The students all have the ability to describe a lived experience. 


\section{Chapter Four}

Data Analysis

\subsection{Data Collection}

Introduction

The purpose of this paper was to explore the different art approaches, instructional strategies, art activities and assessments used in an alternative learning school setting to help deal with their own personal social stressors. This chapter discusses the different art approaches used in an art classroom, alternative learning school setting, and clinical observation settings Through observations; document analysis of lesson plans, student art activities, and my own lived experiences as a practicing classroom art teacher in both settings, I was able to see firsthand how the different art and art therapy approaches employed in each of these settings, I also observed these.

The research questions that framed my investigation were:

1. What art approaches are used in secondary school settings?

2. What art approaches are used in alternative learning school settings?

3. What art therapy approaches are used in alternative learning settings?

\subsection{Lesson Plan}

The following lesson plan was used in both the regular art classroom and the alternative learning school classroom.

Title: Emotion Boxes 


\section{West Virginia CSO Standards:}

FA.VA.O.VAI.02 - Communicate original and personal ideas in a variety of media, techniques, and processes to create two dimensional and three-dimensional artworks

FA.VA.O.VAI.1.03 - Use materials, tools, and technology in a safe and responsible manner

FA.VA.O.VA1.3.03 - Apply problem solving skills in the creative process selecting subjects, symbols, and ideas for use in their own artwork

\section{Lesson:}

I started the lesson by asking the students if they had emotions. I asked them if they had a way to cheer themselves up to have something that they could go to, to remind themselves of how they can overcome their struggles would they use it. Students were introduced to the emotion boxes. I told them that they needed to come up with a negative emotion one that they felt fairly regularly, then they had to come up with a quote or saying or image that if they were feeling this negative feeling they could look at that and cheer themselves up. Students were then given two perfect square pieces of paper. They were shown how to layout and design their inside and their outside of their box so that the images they designed were where they were supposed to be. The outside design was the negative emotion, the inside was the quote or picture or saying that cheered them up. The students could use the following supplies to complete the assignment: pencils, sharpies, colored pencils. Markers, watercolors, and crayons.

\section{$\underline{\text { General Secondary School Art Classroom }}$}

In the general art classroom, I observed students to be mostly concerned with grades, life, and their future. The students talked to each other and compared issues and pictures. They all 
seemed to have similar stresses and enjoyed talking to the other students about their emotions.

The pictures (Figures 5-8) are of artwork that was created within the regular art classroom.

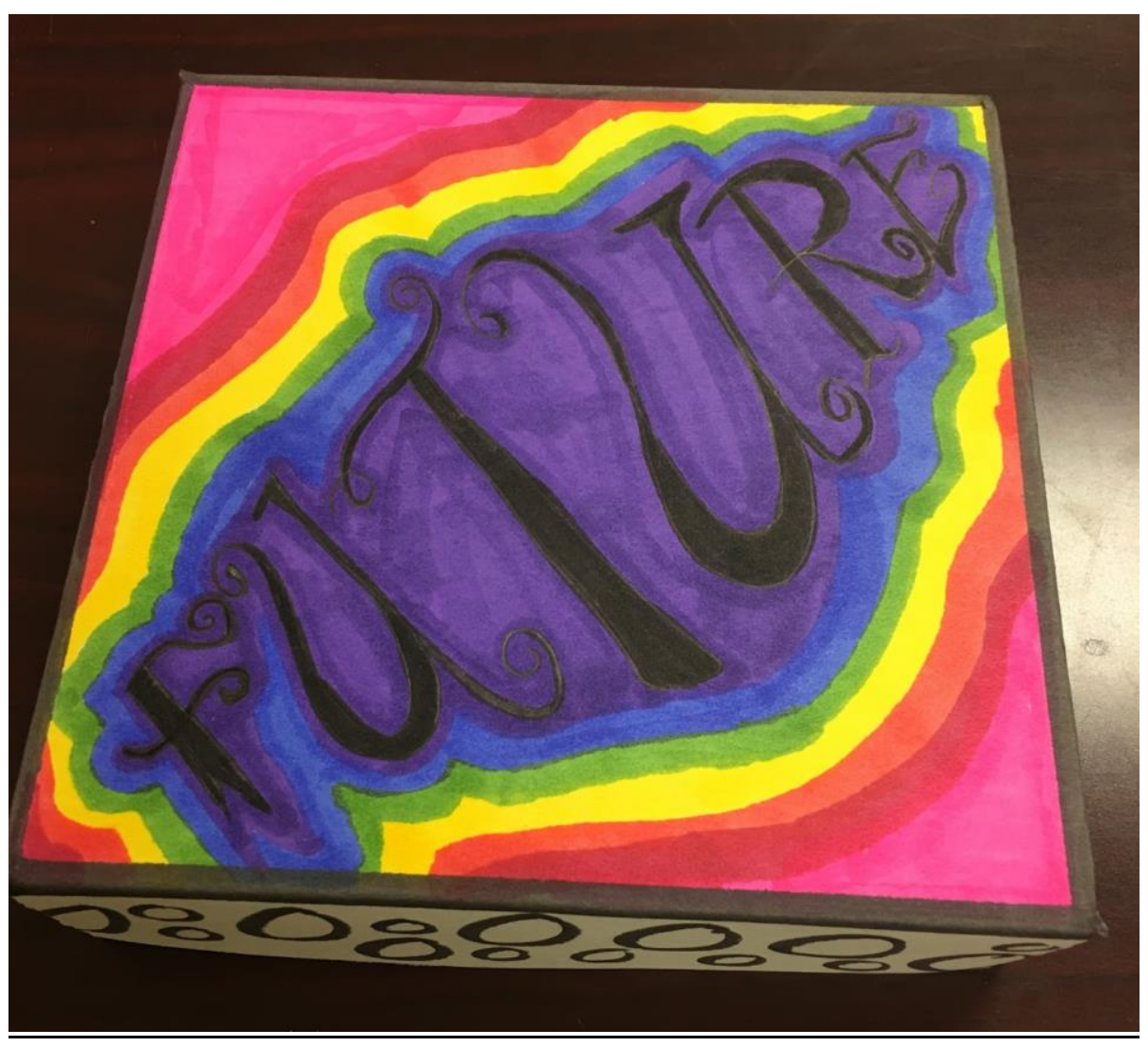

Figure 5 - Example of student A's outside of box 


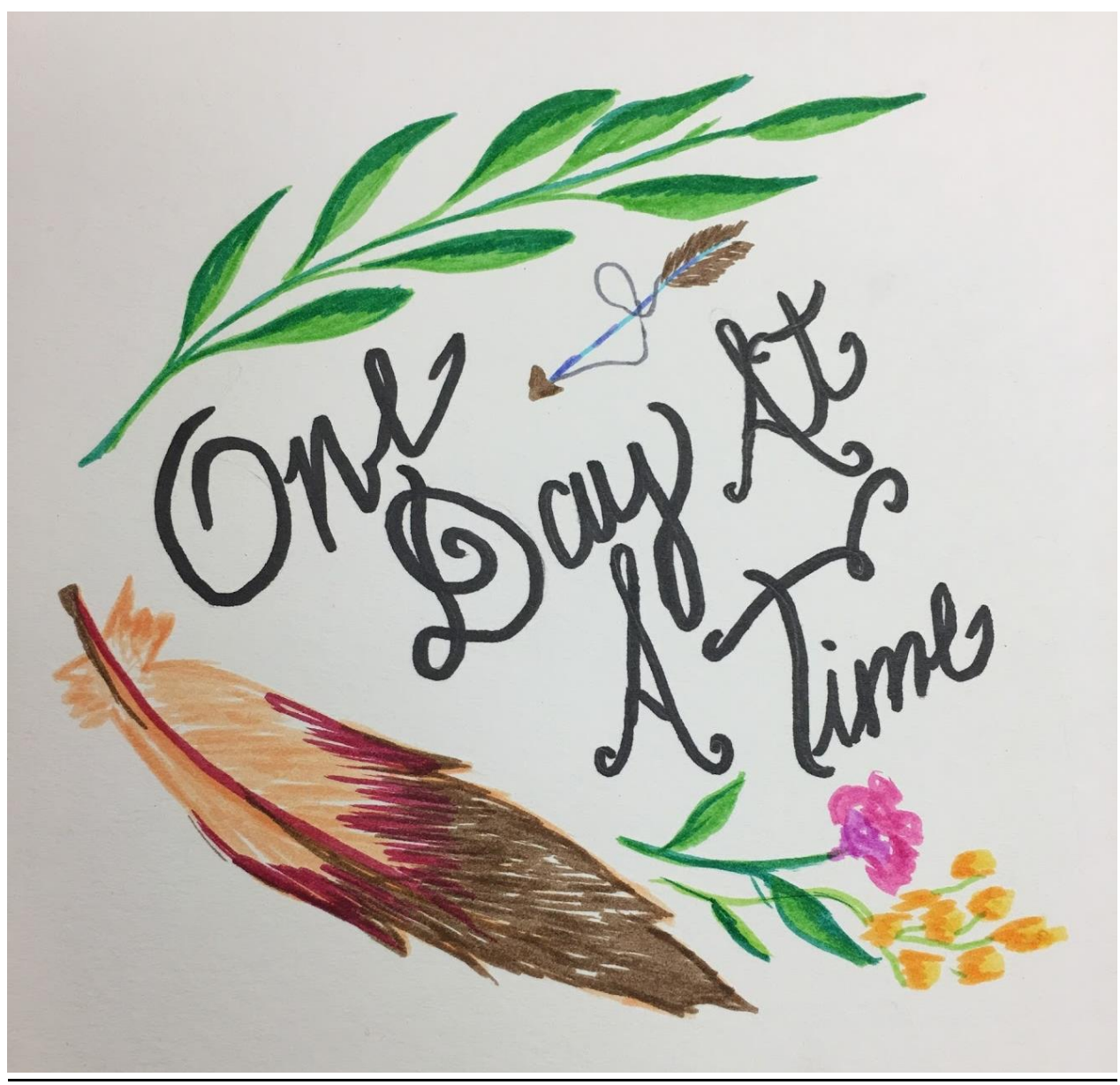

Figure 6-Example of student A's outside of box 


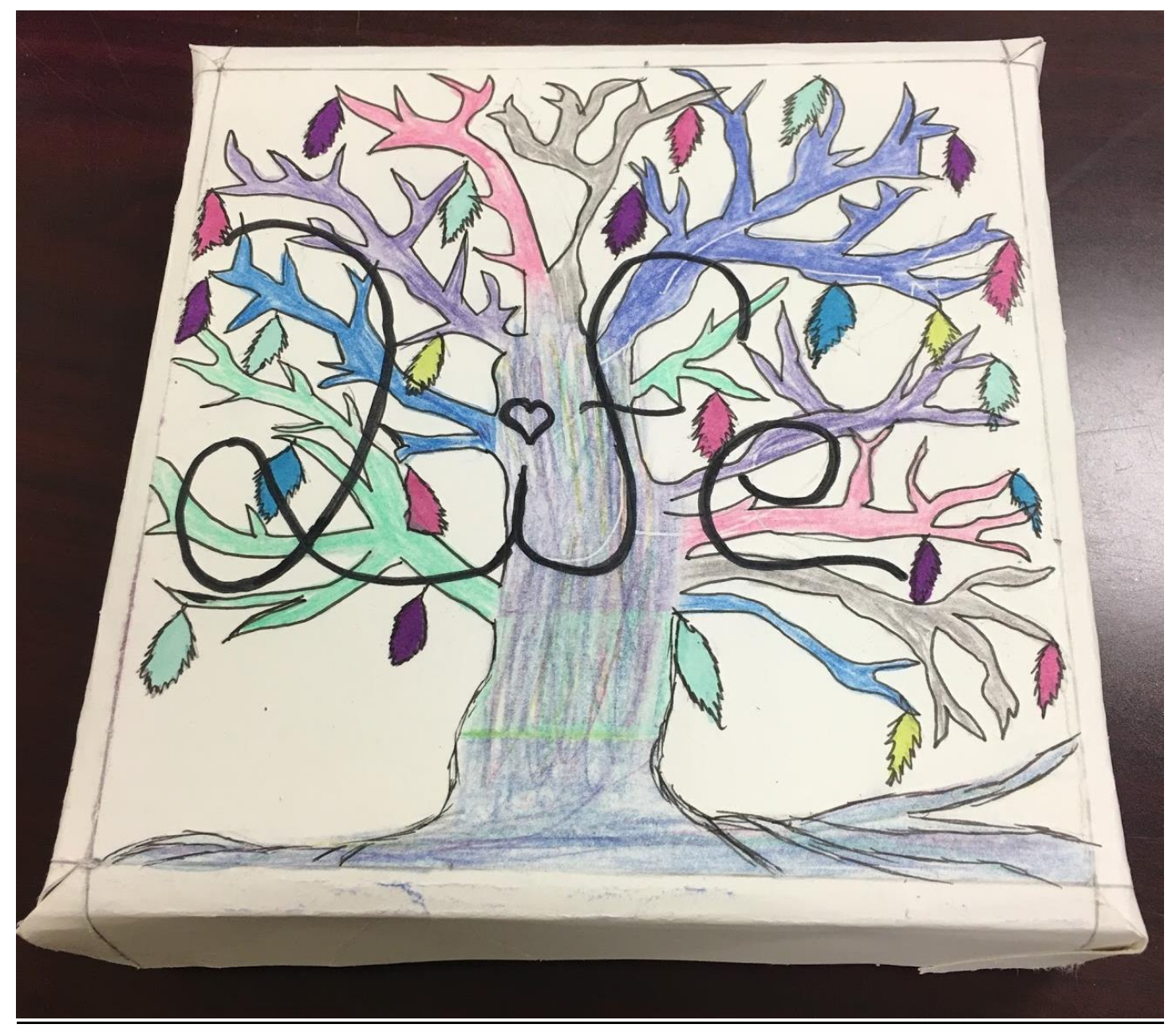

Figure 7 - Example of student B's outside of box 


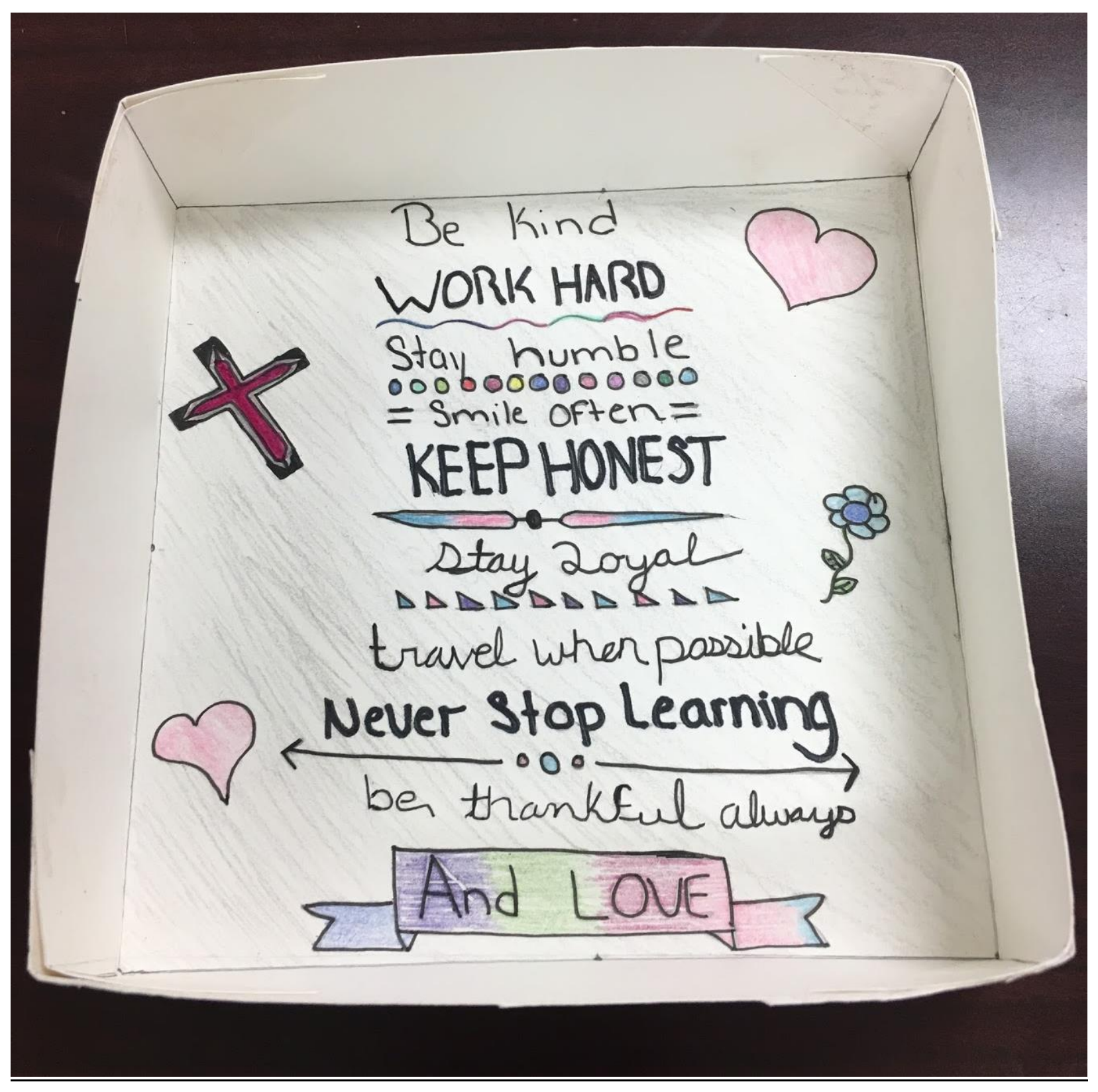

Figure 8 - Example of student B's inside of box 


\section{Alternative Learning School Art Classroom Setting}

In the alternative learning setting, I observed a variety of different concerns: Here, student's main issues that were upsetting to them were not having a stable family environment, drug influence and having to struggle with having a part time job to try and help pay bills and support the family. The students all talked at their tables and they seemed to bond over similar issues and really opened up to one another. The pictures in Figures 9-12 were created in the alternative learning school art classroom. 


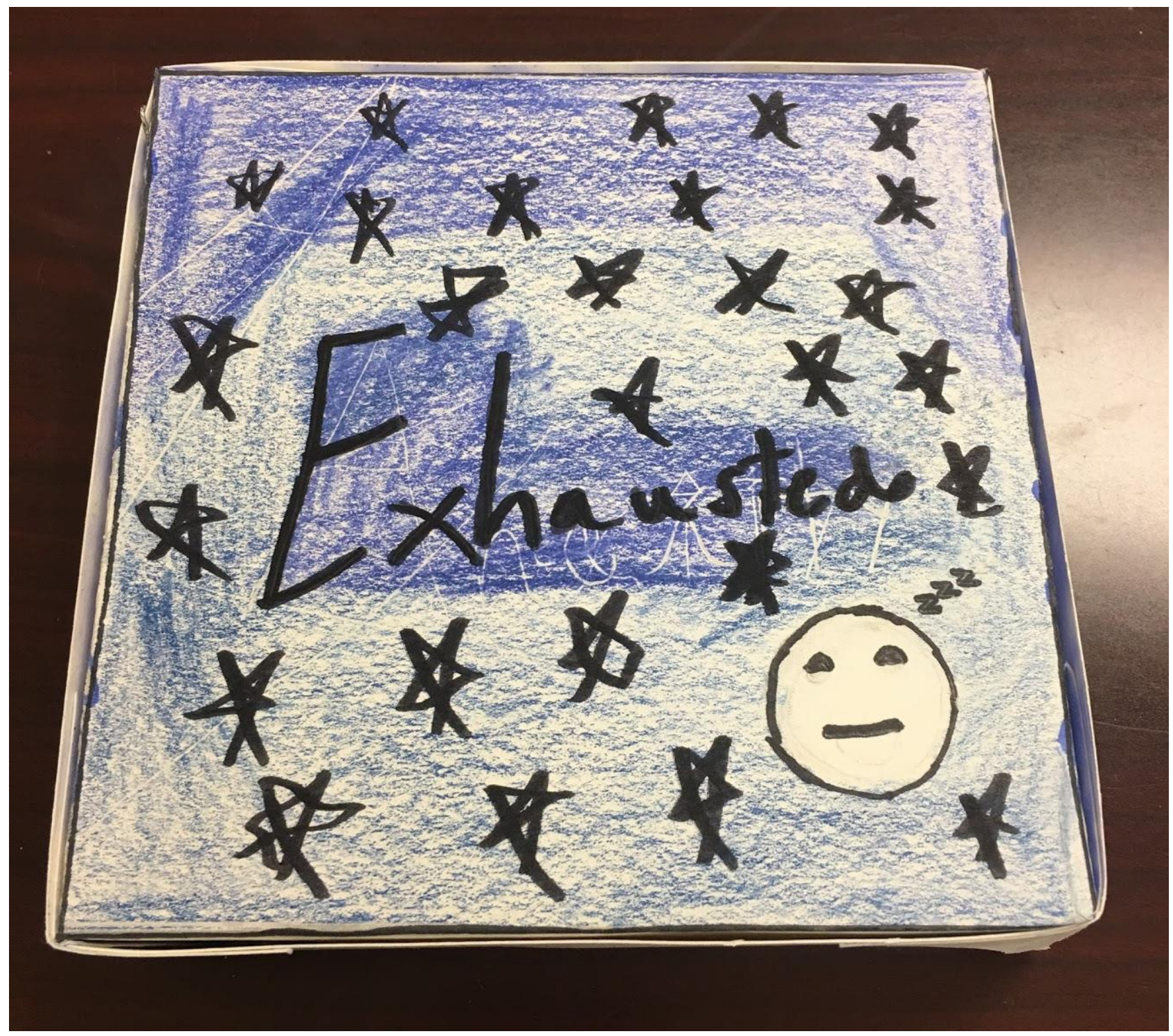

Figure 9-Example of student C's outside of box 


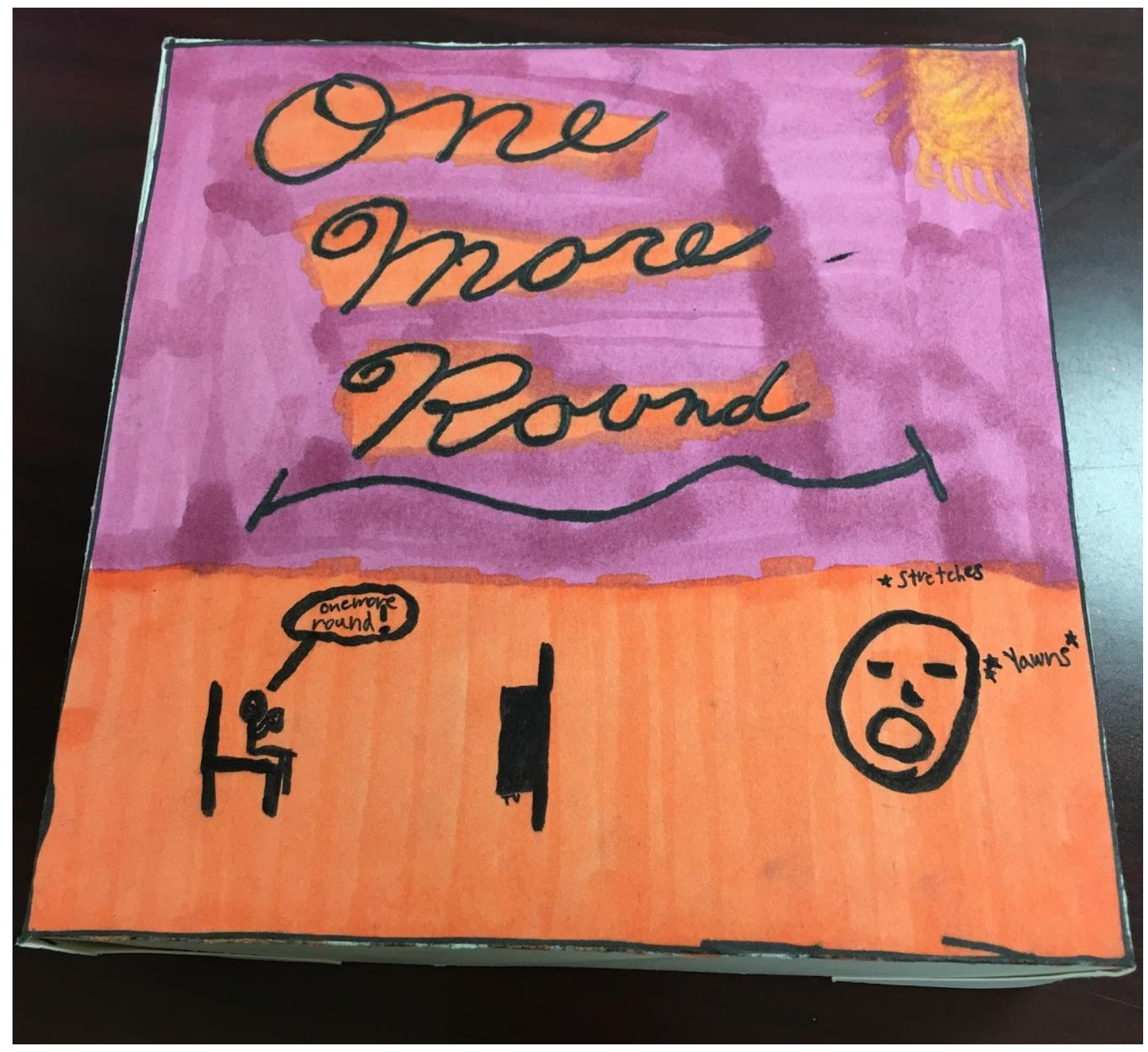

Figure 10-Example of student

C's inside of box 


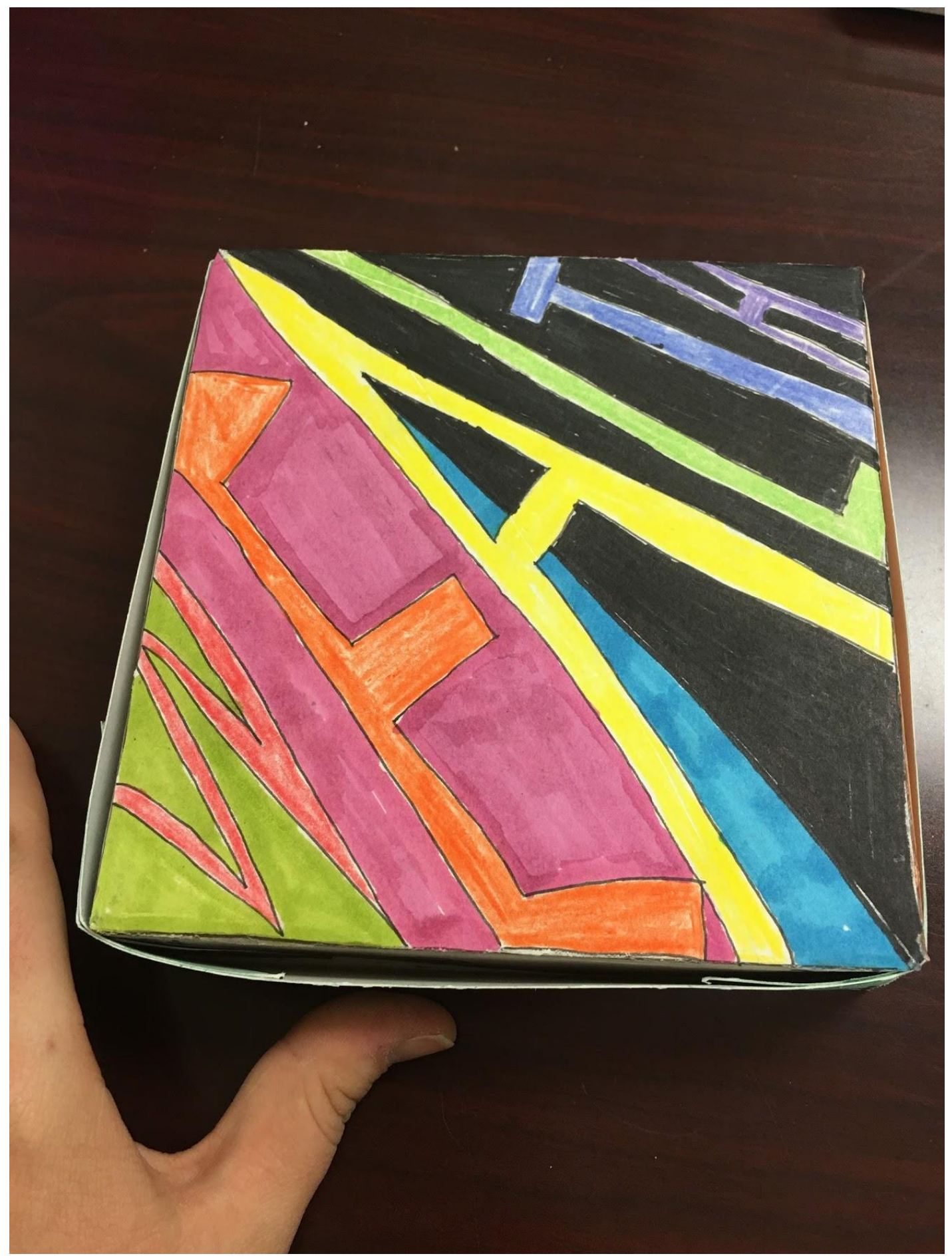

Figure 11 - Example of student

D's outside of box 


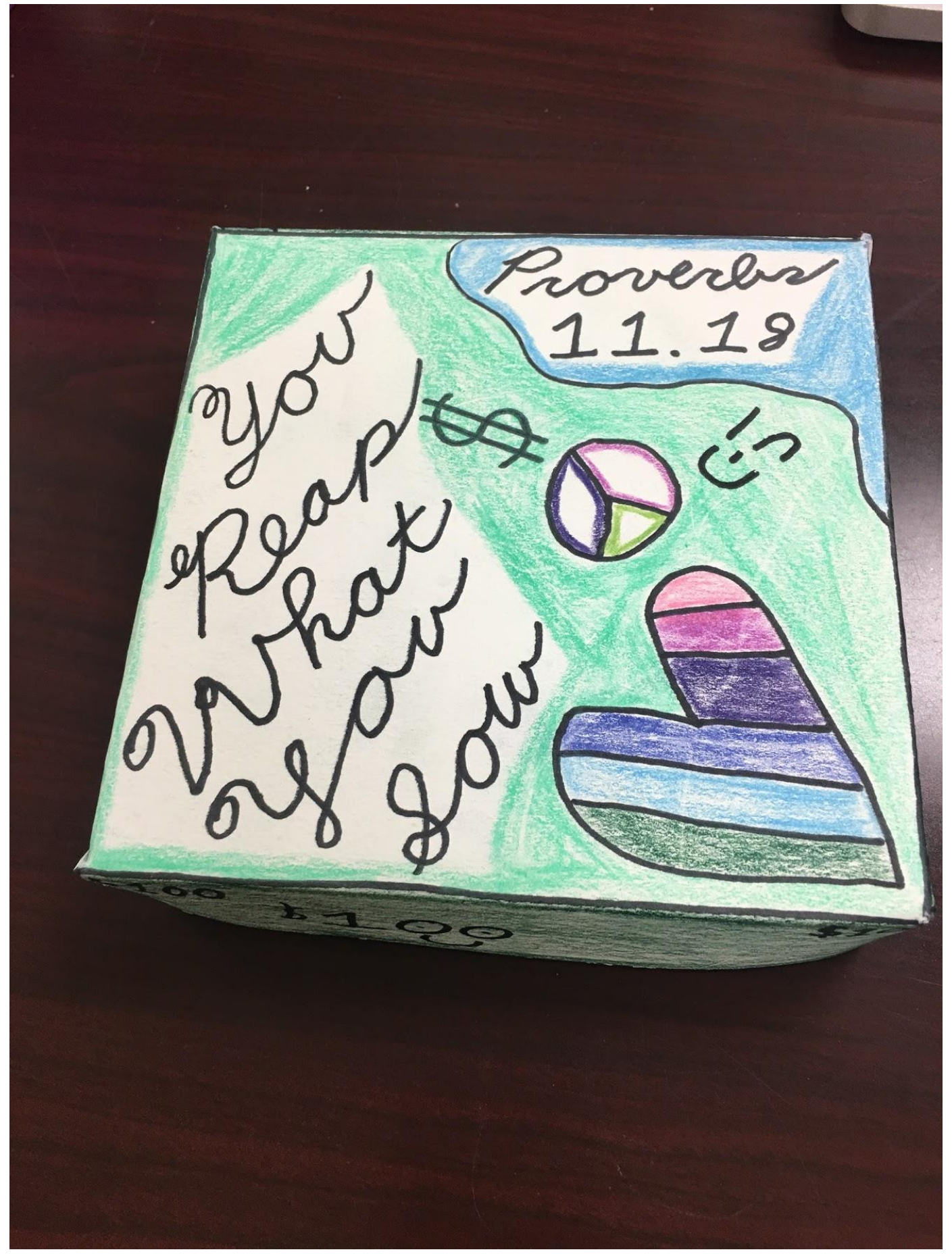

Figure 12 - Example of student D's inside of box 


\subsection{Clinical Setting - Site A}

My experience with art therapy in general is very slim. I honestly was not sure what I was going to see with this experience. My understanding of what an art therapy session was to have the client come in and lay down on a sofa with the art therapist holding a clipboard, taking notes while the client talked. In my mind, Art Therapy was the therapist holding up black blotted pictures asking the client what they saw. I know that these visualizations are most likely coming from what the media wants the public to perceive therapy as. I am just as guilty. When I experienced therapy through this class, I visualized something new.

Through my own personal teaching experiences as well as through observations of art therapists within a course I took in my graduate program, I was able to watch the art therapy process at two different sites. Both locations I have had different experiences.

At School A, I observed a girl's lunch group. The guidance counselor organized this group to talk about self-confidence as the girls transitioned from fifth grade to sixth grade, which is at the middle school. There are only 12 girls in the group. These girls come from various backgrounds, however the general area of School A is a low income and rural area. There was one rule that the guidance counselor had with the girls - that being whatever we talked about stayed in the group. They were not to share any information shared within the group with any other students. This was a self-confident group and we were there to build each other up, not to tear each other down.

At Site A, the private therapist's office, I observed evening therapy sessions. Clients came locally as well as surrounding counties. I also observed a wide age range of clients from small children to older adults. The therapist used mainly talk therapy, but she also used some 
play therapy and art therapy. The therapy office has a file cabinet that the therapist would take notes after the session was over and store them in there. The file cabinet was locked always and could only be opened with a key.

In the girls group at lunch, as stated earlier focused on self-confidence, however the group turned into a safe place for the girls to ask girl things. At the beginning of the group the girls were asked to write two things that they would like to discuss in the group about moving up to middle school and their self-confidence. The answers that we received back we mostly: how to handle a bully, how to know if a boy likes me, how to get around a big school, how do I make new friends, what if I do not know anyone in my classes, and what should I expect from a girl's period.

Some of these girls do not have strong woman figured in their life and they had some questions of things that they needed help understanding as a young woman. The counselor and myself have done the best we can by providing the girls a place to talk and understand things openly. We have discussed ways to handle being bullied and the steps to take to avoid the situations. The topic of boys was a delicate subject, as we are in a public-school environment and we just encouraged the girls to stand up for themselves and not let boys tease them or pick on them. About transitioning into the middle school, we told the girls that they will be getting a tour of the school, they will get schedules, and the teachers will be understanding the first week of classes if they are late. The teachers understand that they are adjusting to a new school and may have difficulties finding classrooms. Getting involved with the school was an idea we shared with the girls about making new friends, if they like sports or hobbies, the middle school has a lot of opportunities to join a sports team or a club. The middle school has more variety of activities for the girls to take part in than the elementary schools do. The girls were amazed at the 
opportunities they would have in the middle school. They had no idea that so many clubs and sports were offered to girls. The last topic that we covered with the girls was their menstrual cycles and body changes. We covered as much as we could about, keeping clean by taking showers and how to change out feminine products. Every week we covered something different and at the end of the group the girls said that thanks to us they felt more confident not only in themselves but to transition to middle school.

One activity that the guidance counselor did with the girls that really seemed to help them get talking was when she passed around a box of crayons and she asked them to choose a color that represented how they were feeling or how they wanted their day to end. After all the girls, had chosen a color she said that we were going to share why we selected the color that we did. The guidance counselor went first to set the example. I then participated next and had chosen a purple color, I said that purple was my favorite color and that it makes me feel happy. I said that I was having a great day and that because I was in a good mood and happy purple represented that feeling. Some of the girls were nervous, or not having a good day, but it's wonderful how just a crayon can change the mood of the room. It helps to talk about a color, and then transition into the feeling. In my opinion I felt that it also helped the girls open up because they were holding something and had something to look at while they were talking.

I did most of my observations at Site A in West Virginia. I observed one therapist and she takes multiple age clients, depending on the reasons they are all there. The building is a very clean place. It has inspiration quotes on the walls and all the seating is soft couches or chairs. Within the office, she also has soft comfy chairs and couches. Her office also has toys and games on shelves or already placed out. One table and two chairs are also present in her office. Dr. Strange says that she likes to leave some toys placed out because some of her patients just come 
in and start playing or drawing and she can start to talk to them easier. She has various board games, card games, and she has a play house with all of the necessary people, furniture and accessories you would need to play house.

The first client that I observed was a middle-aged woman who is going through some rough times and she just needed to talk. She comes on a weekly basis and she only talks. She does not do any other activities with the therapist. The most important thing that I took away from this observation was the power of listening. It did not seem like anyone listened to her at home or in general, and Dr. Strange was the person who listened to her and made her feel important and that her opinion mattered.

The second client that I observed was a high school student who liked to smoke Marijuana. His parents were concerned with the fact that he liked to do this in his free time. He was coming to therapy to talk about what his feeling were on the topic and to share what he could do to potentially stop smoking. She let me share my opinion as a teacher with smoking. I shared that my opinion of smoking in general, whether it is cigarettes or marijuana is that I did not like it, I personally got terrible migraines and I thought that marijuana smelled like skunk. I personally think that this patient smoking was a sign of attention, it did not seem like he got a lot of attention at home or that he felt his opinion mattered in his house. This session was also just talk therapy and he just sat on the couch and did not do any other activity.

The third client that I observed was a fourth-grade boy who would not talk at all. He first came back to office with his grandmother and she filled us in on what was going on. The boy was living with grandma along with his older sister. Mom just got re married and had three younger children at her house. Grandma felt that he was lost at his mother's house, however the boy wanted to be at mom's house and not grandmas. The therapist asked the grandmother to 
leave so that we could talk to just the boy. He did not want to talk. He had his hood up from his hoodie and did not want to share anything. The therapist did a crayon activity with him and he did not even want to pick a color. The therapist drew on a paper and she was trying to get him to add to the picture or conversation. She drew a house in red because she said she was upset because she was currently working on house renovations that were taking longer than expected. The therapist then drew a flower and she said that her day started out ok then it went a little downhill but then it was ending on a good note. She then drew a sun in yellow saying that my day was warm and was looking up. The boy then grabbed a gold crayon and added a stem to the therapist's flower and said it was missing this and not it was complete. The therapist's last detail to the artwork was adding a cloud, not a dark cloud but a blue cloud. She said that the weather was starting to get nice and she could not wait to be able to go outside and enjoy spring and summer. Figure 13 depicts the artwork that the therapist and patient completed.

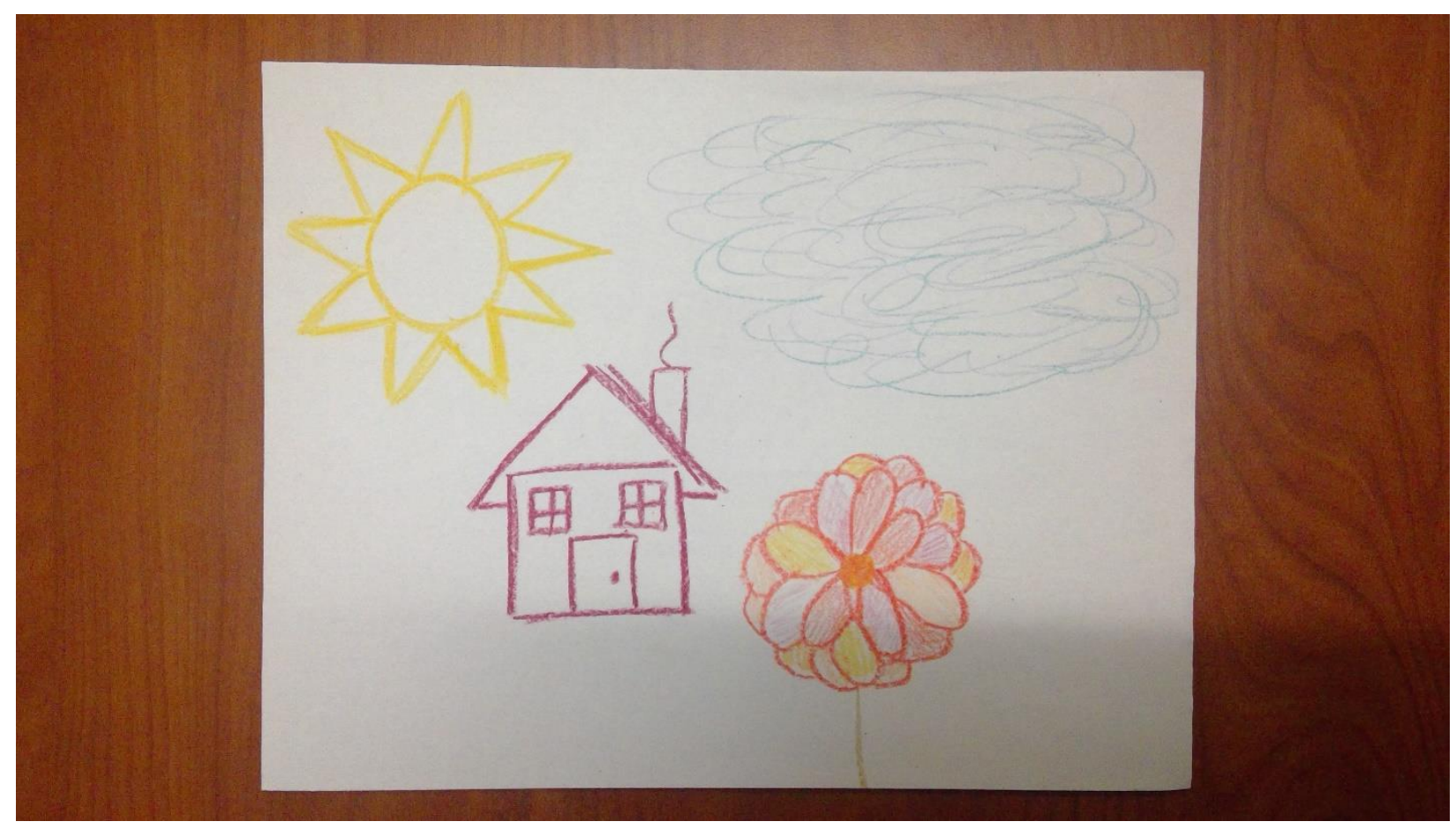

Figure 13 - Example of therapist's drawing with client 
I was excited to hear that a few weeks later this same boy would be coming back in while I was doing my observations. I was curious to see how things were going and to see if this time he would talk. He came into the office and he sat at the table with me and there were Lego's on the table he immediately started playing and building and talking to me. He did not have his hood up this time and he was talking to me like I was his friend. While this was happening the therapist came in and said okay since you two are talking I'm going to go talk to grandma. The boy kept talking to me sharing that he moved back home with mom. That he was helping mom, and that he liked grandma as grandma and not a second mom. He told me that he did not like school right now, but gym and art were his favorite subjects, that he felt calmer after those classes and that he felt prepared for the rest of the school day ahead. Sports was a big topic with this young man he liked to watch and play basketball, and he loved to run, he hoped that once he got to the middle school he could join the track team and run. He was sharing so much information with me while he was working with the Lego's I could not believe that this was the same child that came in a few weeks prior and would not share anything. The therapist came back in the office alone and she asked what we discussed and we both shared the things that we talked about. The therapist said that things seemed to be going very well, that her discussion with grandma was good and that the boy was treating the grandmother better now that he moved back home. Observing this patient was interesting to see the first meeting and then a meeting again to see the change. Therapy can change the lives of people and this was a great example. This was also the first patient for myself to observe the play therapy aspect.

The fourth patient I observed were the mother and daughter, of a patient. I honestly thought that they were grandmother and granddaughter at first. I found out after the session that the woman's son's girlfriend was pregnant and had a baby and with no DNA testing the woman 
adopted the baby later to find out it was never her sons. He was not the one to get her pregnant. The mother and daughter came into the office and sat on the couch. The mother's therapist is Therapist A while the daughter's therapist is Therapist's B who is a colleague. It started as a kind of group therapy to get everyone on the same page as to what is going on. The mother is older and has a series of medical issues, including now ovarian cancer. The daughter has been tested for autism, and a multitude of other mental health disorders, and all the tests have come back that she has all of them. So, the daughter does not have a specific disorder that she identifies with. The mother shared her updated information with her cancer and all her appointments and the daughter seemed to be a little nervous about her mother having surgery and not being able to be with her. The daughter also shared that she was going to be starting a new job soon. Once everyone was on the same page Therapist B took the daughter over to her office to talk, leaving the mother with Therapist A and myself. We just used talk therapy and the patient sat on the couch. The mother shared with us that she really is not nervous yet, but maybe once the surgery is closer that she will be. The therapist took the calendar that the mother was looking at to tell us all of her appointments and the daughter's appointments and the therapist wrote in on a blank day "me time." The therapist said that she was doing a great job being a mother, but she needed her me time, and that once she had this surgery she would not be able to be super mom, and that the daughter and her husband were going to have to step up.

These patients I was also able to see again. They came back in and we did the same thing where we all started in office and used talk therapy to make sure everyone was on the same page. At this session, we learned that the mother had a set date for her surgery, that the hospital had called her and that is was scheduled. The daughter started her new job, she works at a comic book video game store. I did not really see progress in this session however I did see that the talk 
therapy just helps. It helps the mother and daughter say the issues that they have out loud and then how they can get through them together.

The fifth patient's that I observed were sisters, they are middle school aged. We again just did some talk therapy with the girls. They did not want to do any other activity. They do not want to see their father. From what I understand the father did not do anything to the girls physically it just seems like it is a mental block for the girls. The mother and father are divorced, and they are both already re married. The girls seem resistant to the new step mother as she seems to want to cause more drama then necessary with the girls and their mother. The father does not seem to want to give up his rights to see the girls. In the therapy session, the girls shared how they feel and the therapist is giving them tips on how to handle the step mother when they are visiting their father. She told them that being in the middle of things is not where they should be situated.

The sixth patient that I observed was a woman in her 40's. She has an excellent job, she lives on a farm on her parent's property raising goats. She got married to a man and they have a beautiful daughter together. The husband suddenly said that he didn't want to live in West Virginia, and the long distance was going to be hard. He works for oil and gas and he travels a lot for his job. He currently is living and working in Ohio, the drive is only three hours. The mother is upset because he rarely comes to see his daughter. They are not divorced. And he still has mail sent to her house on the farm. He does just show up whenever he wants and driving toward the house and calls the mother after he has already left. The mother's main struggle is that she is scared to leave the house and go on trips so if the father decides to drive out he can see his daughter. The therapist's main point that she stressed with her is that she cannot live in fear of the father coming and her daughter not seeing him. She must live her life how she wants to 
and not always question her decisions. She planned a trip to Disney and kept telling him that herself and the daughter were going that if he wanted to come he needed to let her know. He said no and the mother took the daughter on the trip to Disney, and he was stunned that she went through with the trip. The main therapy that was used in this session was also talk therapy.

The seventh patient that I observed was a grandfather and a granddaughter. She was now living with the grandfather; her mother has been involved in some not good choices. The granddaughter was having a hard time adjusting to living with grandpa. The therapist brought just grandpa back and had him discuss what was happening. He said that his wife had just been diagnosed with blood cancer, and he not only had the one granddaughter but the baby granddaughter as well. He was trying to balance out having the grandchildren and being there for his wife and keeping up with the farm. He said that the granddaughter was giving him a hard time about doing the simple things after school such as homework, getting a bath, and getting ready for bed. Once we had a short therapy session with grandpa we then brought back just the granddaughter. She talked to us a little about what she was feeling. She had said that she felt a little abandoned. The therapist only asked her a few questions before she became too restless to talk. The therapist told her that she could play house if she wanted. This was the only real time that I have seen a play therapy session. As the girl was playing house we noticed that the mom was in the bed and the little girl was taking care of the mom. The granddaughter told us that she had to take care of her mom sometimes because dad was never home. This little girl's home life was not stable and by her living with grandma and grandpa was a blessing and she is so loved. It breaks your heart when you have a child that doesn't understand that they will be ok and their life will be better by living with grandpa and grandma. They only want their mom even if she isn't the perfect person. 
The eighth patient was a middle school girl who just had back surgery. She was referred to the therapist from her school counselor because she was on suicide watch. That her mother and her friends had recommended her to therapy after she said she wanted to kill herself. She was having a hard time keeping up with school because her back was hurting so badly, one she missed a lot of school, so she lost contact with her friends and missed out on her socialization. Dr. Strange used talk therapy with her and talked about everything. The girl had just had the back surgery and she said she was feeling great and that she was happy to be back in school and be with her friends. Dr. Strange talked with the mother as well and the next time that they have a session Dr. Strange would like to talk to the mother alone and see what is happening at home from the parent's perspective.

The ninth and final patient that I have observed was a young boy first grade age. He is very bright and knows a lot about everything. He is living with grandma because mom is in prison for the rest of her life. He has seen a lot of things for a young child and has nightmares. Dr. Strange did some talk therapy with him but then the three of us played multiple games of UNO and she incorporated some play therapy into the session. Once we were playing UNO, he opened up to us a little more. He giggled, and he really enjoyed himself. It seemed as if the nightmares and the pictures in his mind disappeared for a little bit.

I feel that these patients could have benefited from art therapy. Even if it would have been a Zen tangle coloring sheet. The patients would have been working on something while they were talking. I personally know that when I am creating art I talk more. It is like you are distracted from something that your mind just opens up and lets out what it needs to. I feel that art therapy isn't just art that its art and talking therapy and that together you can get a better answer from the patients. 
I have learned that in general art therapy is a great thing. That almost everyone responded by saying that by doing some type of art the patients they observed opened up more. We also talked about how art doesn't necessarily have to be difficult or hard like painting or drawing it can be as simple as a coloring sheet. I am also grateful for the techniques that Lisa has shared with us about how to get patients talking and how to incorporate more art into therapy. She shared with us the technique about how to pass the patient a box of crayons and have them choose a color based on a particular mood that they are feeling. Then to follow up with having the patient share why they chose that color. Another technique that she shared with us was one where the patient selects a color and they scribble of the drawing for a few seconds. After they feel that their picture is complete they may turn their scribble drawing into pictures that they actually see. I really liked this project because you create things from nothing and they turn into real pictures that your mind created without having the intentions to. One other activity that she shared with us was an activity that we created a symbol and she tied it to our experience with art therapy. I felt that this was beneficial because it gave us all time to reflect on what we have learned from this class. I have learned so such from going to the round tables and discussing with others what they have observed, participating in the little art activities that Lisa provided for us, and observing firsthand what it's like to be a therapist. I am ready to become a therapist full time. I loved observing and I enjoyed that Dr. Strange let me share my thoughts with some of the clients. I felt that even after my long day at work teaching I was always excited to go and observe and see how therapy really works. My view of therapy and art therapy has changed. Therapy is not just going into an office and laying down on a couch while the therapist takes notes the whole time and the only thing that the therapist says is and how does that make you feel. Therapy is so much more than that. From what I observed therapy is talking about what is 
going on in your life and figuring out a safe way to handle it. Therapy can also include play therapy where the patient can actually act out scenes with dolls, play a game of cards or build with Legos. Art therapy is also not just an Art Therapist holding up ink blots and asking what do you see? Art therapy from what I observed can be simply drawing a picture together, coloring or choosing a color crayon from the box and talking about it.

This is my third-year teaching art. All three years I have taught primarily elementary level students. All three years I have been teaching in a different county. Each county had a different art schedule and a different budget. My first year teaching my students had art every day but on a nine-week rotation, I traveled between two schools. My second year of teaching my students had art once a week but they had art all year, I traveled between four schools. My current year of teaching I have had my students once a month, as long as a holiday or snow day did not interfere.

I taught art in ten different elementary schools as well as taught art at one high school. I see a lot of students and I feel that art in important in everyone's life. I try and incorporate art therapy into my high school's students at least three times a week. They have an art journal and I give them prompts and sometimes I don't. I let them draw and write in them. I collect them at the end of six weeks and I look through them. Unless the students specifically ask for me to look at a page or to read something I just look at their journals for completion. All of my students do the activity and most of my students have given me positive feedback on the activity. They said that it gives them at least five minutes from their crazy day or night that they had to have reflection time and to put their feelings on paper. I cannot stress enough how important art in in life, and this class has taught me to merge art into everyday life to make feelings easier to handle. 
By using self-efficacy as an art therapy approach as stated from earlier, which is the belief in one's ability to influence events that effect one's life and control over the way these events are experienced, an Art Teacher could incorporate a lesson plan that focuses on the student's mind. The lesson could focus on releasing negative or positive energy through their artwork. Students would be given a choice of a directed or a free form project. By having the mental break and just creating what comes to the students can help balance their minds and make them feel that they are in a safe and open space. The students would have the freedom of selfexpression, and they could voice their mind or opinion. By using this the way, they feel they can control how they feel about future events. That knowing they have a separate space to attend they can experience events, but have a place to lay all their emotions out when it is over.

\subsection{Healing Power of Person- Centered Arts Therapy}

It is hard to convey into a written statement the depth and power the expressive arts process. My own personal experiences are celebrated through art, and journal writing.

The time following my mother's death was nothing short of life changing. As a 25-yearold young woman, I thought I still had plenty of time with my mother. I never thought my final hug with my mother was going to be my last. Her death came suddenly, by an accidental gun shot, and I was out of state in West Virginia. Home is in Pennsylvania, not a long distance but at the time it was long enough. I remember receiving a phone call from my grandfather asking me to drive home late that night, I was confused but I drove the hour and a half home un aware of the situation until I made it home. When I pulled into my driveway, the only thing I saw were flashing cop lights. I parked my car in the middle of the driveway and the first person I saw was my brother, he told me that mom was gone. I didn't believe him so I looked for my father, I could tell it was true when I saw the look on his face. The next thing I remember doing was 
screaming. It didn't even make sense, but I was just screaming, no words. The screaming just felt right, I had these emotions that needed out and screaming was my answer. Making noise. The next thing was crying, and then the numbness starting setting in.

After the funeral and the family left, and everything came back to reality. I felt completely alone and helpless. I had to go back to work an hour and a half from home, with no close friends, or family around. I felt completely isolated. At this moment is when I turned to writing in my journal and creating art. The writing in my journal turned into writing letters to my mother for the things that she was missing. I felt as though I was connected to her still and that I was telling her what was happening. My emotions that I felt ranged from anger, to hatred, to becoming okay with the situation. Below are examples of my expressive art that started to help me heal (Figure 14). 


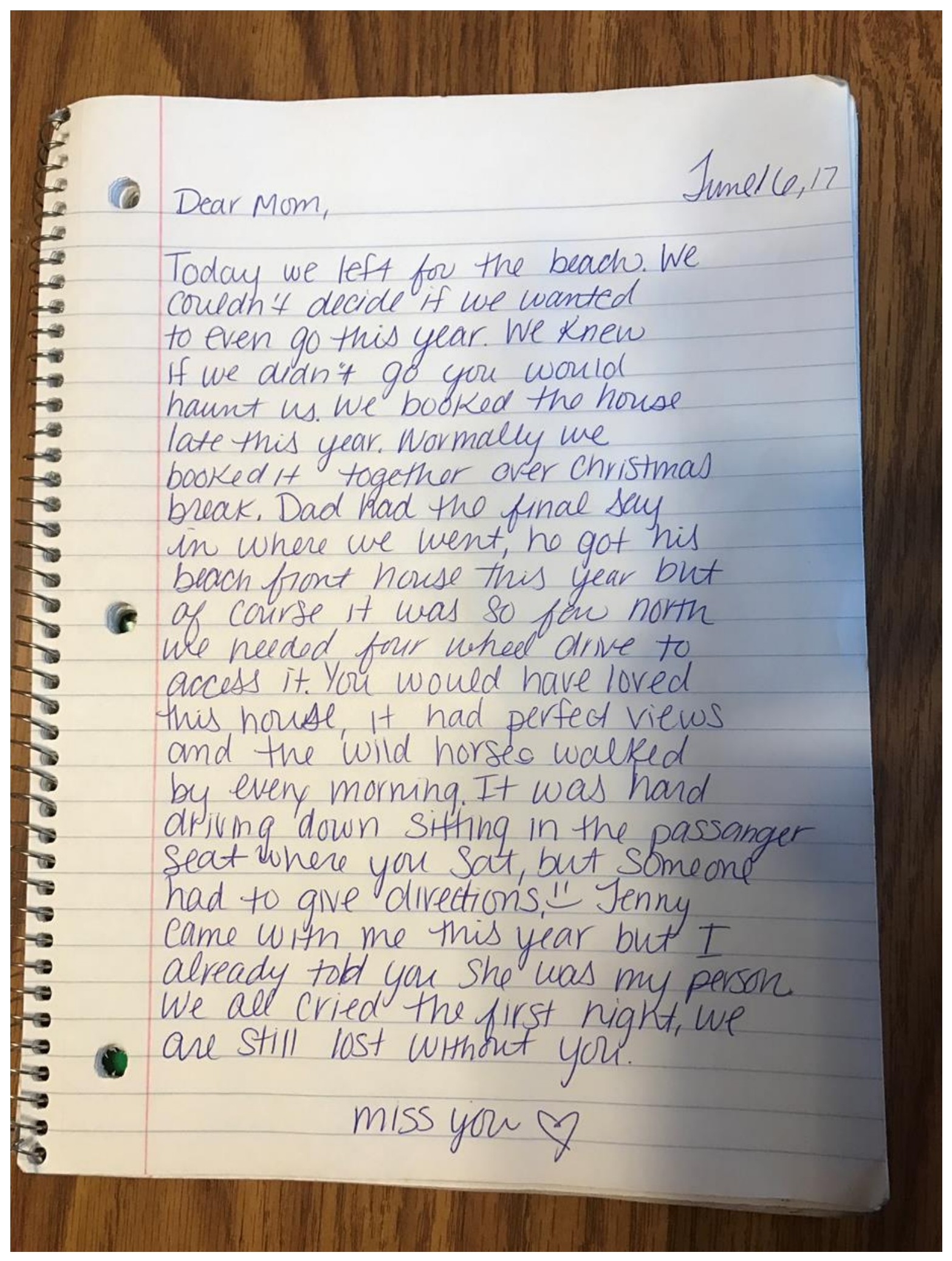

Figure 14 - Personal journal entry 


\subsection{Summary}

Students no matter if they are enrolled in a regular setting classroom or at an alternative learning setting, they all are going through stressors and anxiety. By involving themselves into art students appeared to be less stressed, and were given a way to express themselves. Students opened up and they shared their anxieties with each other. By using art and words feelings can be released that have been built up inside. The emotion boxes that were created is a fitting example of how emotions can be let out from within. Patients young and old can have situations that they would need to receive therapy for. They all have unique situations. 


\section{Chapter 5}

Findings

\subsection{Discussing of the Findings}

The purpose of this paper was to explore how art therapy can be affective in schools. Art therapy can be affective not only in schools but in outside of school settings as well. A summary of the findings, interpretation of the findings, suggestions for art therapy practice, and proposals for further research are presented in this chapter.

\subsection{Summary of the Findings}

From the research questions the following themes emerged:

The collected data suggested that when art is participated in, students respond in a positive way.

My findings appear to suggest that when an art class was provided the students seemed to break out of their shell. The students participated in discussions at their tables, then continued onto sharing personal information, such as how their days were going. The table discussions often turned into an emotional release, leaving the students in a better mood. Gestalt Art Therapy can be addressed here because the students reacted in a positive way because they were surrounded by a positive and safe environment. They were influenced by their surroundings. When students only receive art once a month, it is sending a message to them that art is not as important as other subjects. Art is an important subject and it should be protected not the first to go with budget cuts. Without art in our lives we would not be happy with the world that we live in. Students are affected in the amount of art they receive. If a student only receives art once a 
month if that, they are not being fully creative, compared to a student who receives art once a week. The students get to be fully emerged into art when they have the class more often.

\subsection{Implications of the Findings}

Within this sample, it can be implied that:

1. Art should not be cut from schools. Schools need to keep the arts in the schools and start including them within the budget, not making them the first to go.

2. By providing more information about how art therapy can affect students in schools, more schools will be more likely to positively support the art program in their schools.

3. Art is the best type of therapy for those who do not use words to communicate, or who do not want to talk to express how they feel.

4. Art needs to become a priority in schools and needs to be provided to students at minimum once a week.

\subsection{Suggestions for Future Research}

The last issue, which was not addressed but needs further research can art therapy approaches improve self-efficacy with students who are in alternative learning setting school? A study is needed to investigate how art in alternative learning school settings can positively help students with self-efficacy.

1. A study to investigate how art therapy in schools can improve the wellbeing and selfefficacy of their students. 


\section{Bibliography}

American Art Therapy Association. (2017). Retrieved May 28, 2017, from https://arttherapy.org

Aspers, P. (2009). Empirical Phenomenology: A Qualitative Research Approach (The Cologne Seminars). Indo-Pacific Journal of Phenomenology, 9(2), 1-12.

doi:10.1080/20797222.2009.11433992

Bland, P., Church, E., Neill, S., \& Terry, P. (n.d.). Lessons from Successful Alternative Education: A Guide for Secondary School Reform.

Bryant, B. (n.d.). Katy Independent School District. Retrieved March 11, 2017, from http://www.katyisd.org/dept/finearts/Pages/The-Importance-of-Fine-Arts-Education.aspx

Buchanan, J. (2017, July 10). Albert Bandura: Self Efficacy for Agentic Positive Psychology. Retrieved May 23, 2017, from https://positivepsychologyprogram.com/bandura-selfefficacy/

Creswell, J. W. (2003). Research design: Qualitative, quantitative, and mixed methods. Thousand Oaks, CA: Sage Publications.

Denzin, N. K. (1985), Emotion as Lived Experience. Symbolic Interaction, 8: 223-240.

Forrester, William C., "Art Therapy in the Mainstream Classroom" (2007).All Regis University Theses.Paper 60.

Fraenkel, J. R., \& Wallen, N. E. (2006). How to design and evaluate research in education. (6th ed.). New York: McGraw- Hill.

Gestalt Therapy . (n.d.). Retrieved July 22, 2017, from http://www.goodtherapy.org/learn-abouttherapy/types/gestalt-therapy

Lewis, B. D. (2017). Why are more American teenagers than ever suffering from severe anxiety? The New York Times Magazine, 1-12.

Malchiodi, C. A. (2014). Handbook of Art Therapy. New York: Guilford Publications.

Merriam, S. B. (1998). Qualitative research and case study applications in education. San Francisco, CA: Jossey- Bass.

Neighbors, J. (2016). Mental Health in Schools Program and Policy Analysis. UCLA Center, 4.

Rogers, N. (2016). Person-Centered Expressive Arts Therapy. In J. A. Rubin (Ed.), Approaches to Art Therapy (pp. 230-248). New York: Routledge.

Ruppert, S. S. (2006). Critical Evidence How the Arts Benefit Student Achievement. National Assembly of State Arts Agencies.

Sarah. (n.d.). American Art Therapy Association. Retrieved June 19, 2017, from https://arttherapy.org/ 
Says, H. (2014, May 18). Art Therapy Helps High School Students Express Themselves. Retrieved July 5, 2017, from http://www.arttherapyblog.com/mental-health/art-therapyhelps-high-school-students-express/\#.WWfKRoWcHZs

Sisk, J. E. (2017, May 25). Alternative School. Retrieved from Encyclopedia of Children's Health: healthofchildren.com/A/Alternative-Schools.html.

Waters, D. J. (2017). Phenomenological Research Guidelines . Capilano University

West Virginia Department of Education. (n.d.). Retrieved May 25, 2017, from http://wvde.state.wv.us/ 